DNA Library of Life, research article

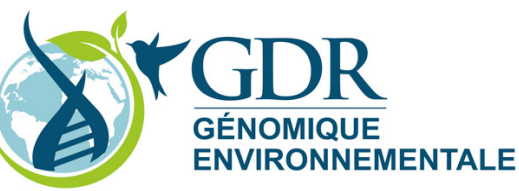

urn:1sid:zoobank.org:pub:A3A6CDB8-BDC8-4CD4-A409-77508FC11530

\title{
Redescription of Proformica nasuta (Nylander, 1856) (Hymenoptera, Formicidae) using an integrative approach
}

\author{
Christophe GALKOWSKI ${ }^{1}$, Claude LEBAS $^{2}$, Philippe WEGNEZ ${ }^{3}$, \\ Alain LENOIR ${ }^{4} \&$ Rumsaïs BLATRIX ${ }^{5, *}$ \\ 1,2,3,4,5 AntArea (www.antarea.fr), Association for the Study and \\ Mapping of Ants from Metropolitan France. \\ ${ }^{1} 104$ Route de Mounic, 33160 Saint-Aubin-de-Medoc, France. \\ 22 Impasse del Ribas, 66680 Canohès, France.
}

${ }^{3}$ Walbru (www.fourmiswalbru.com), Belgian Association for the Inventory of Ant Species in

Wallonia and Brussels, and Rue de la Grotte 23, 4651 Herve, Belgium.

${ }^{4}$ IRBI, Institut de Recherche sur la Biologie de l'Insecte, UMR CNRS 7261,

Université François Rabelais, Faculté des Sciences, Parc Grandmont, 37200 Tours, France.

${ }^{5}$ CEFE UMR 5175, CNRS - Université de Montpellier - Université Paul Valéry

Montpellier - EPHE, 1919 Route de Mende, 34293 Montpellier Cedex 5, France.

${ }^{*}$ Corresponding author: rumsais.blatrix@cefe.cnrs.fr

${ }^{1}$ E-mail: chris.gal@wanadoo.fr

${ }^{2}$ E-mail: cllebas@,free.fr

${ }^{3}$ E-mail: wegnez.phil@gmail.com

${ }^{4}$ E-mail: alain.lenoir@univ-tours.fr

\footnotetext{
${ }^{1}$ urn:Isid:zoobank.org:author:C480F514-D567-4787-AF55-2BE00FB79706

${ }^{2}$ urn:1sid:zoobank.org:author:99DB1C68-3E40-48A7-A665-8BDAF6D8D1C3

${ }^{3}$ urn:lsid:zoobank.org:author:44194EA4-001C-4CE0-9567-F9977E103B40

${ }^{4}$ urn:lsid:zoobank.org:author:0B03EB0F-06EB-413C-A91E-B57CBB22C623

${ }^{5}$ urn:lsid:zoobank.org:author:AFF6B4B9-C054-43A2-8095-84F0FB7B6EE9
}

\begin{abstract}
The taxonomy of the Palaearctic ant genus Proformica Ruzsky, 1902 is confused and in need of revision. The type specimen for P. nasuta (Nylander, 1856), the type species of the genus, was from Beaucaire, southern France, and is presumably lost. Based on extensive sampling of Proformica nests in southern France, including the type locality, we show that the concept of $P$. nasuta has been erroneous for more than a century. We integrate information from the morphology of workers and sexual castes, DNA markers, and cuticular hydrocarbons to re-define species in southern France. This allowed us to provide a new, accurate description of $P$. nasuta and designate a neotype, as well as reference individuals for all castes. In addition, we propose a name, $P$. longipilosa sp. nov., for a species that since the end of the $19^{\text {th }}$ century has mistakenly been included in P. nasuta.
\end{abstract}

Keywords. Ants, Proformica longipilosa sp. nov., Western Palaearctic, molecular markers, cuticular hydrocarbons. 
Galkowski C., Lebas C., Wegnez P., Lenoir A. \& Blatrix R. 2017. Redescription of Proformica nasuta (Nylander, 1856) (Hymenoptera, Formicidae) using an integrative approach. European Journal of Taxonomy 290: 1-40. https://doi.org/10.5852/ejt.2017.290

\section{Introduction}

The ant genus Proformica Ruzsky, 1902 is composed of 25 species (Bolton 2014) restricted to dry and open environments such as steppes, mountain meadows and Mediterranean seashores (Agosti 1994). It is endemic to the Palaearctic region, with a disjunct distribution. A first area extends from eastern Europe to eastern Asia and contains most of the species, and a second area, much more limited in species number and distribution, occurs at the southwestern tip of Europe (Portugal, Spain and southern France). This distribution is somewhat reminiscent of that of the meadow and steppe vipers, the Vipera ursinii species complex, which is composed of taxa restricted to steppe-like ecosystems. Asia and Europe show distinct viper taxa that diverged in the early Pliocene, about 4 Mya (Zinenko et al. 2015). The genus Proformica may have experienced the same biogeographic history as these vipers and several other organisms inhabiting steppe-like environments (Ruano et al. 2011; Sanllorente et al. 2015). Only one taxon, P. nasuta (Nylander, 1856), is reported to occur in both Asian and western European areas.

The taxonomy of the genus Proformica is complicated and in need of revision. The situation is particularly complex in the eastern area, with currently 23 species reported. In Western Europe, two distinct zoogeographical areas can be distinguished, the Iberian Peninsula and southern France, which are separated by a barrier formed by the Pyrenees mountain range. Three described species are currently recorded for the Iberian Peninsula (Collingwood 1976), but at least six forms are recognized by ant taxonomists (Xavier Espadaler, Barcelona, pers. comm.) and substantial morphological variation within each form makes species delimitation difficult. In contrast, only one described species, P. nasuta, has been recorded for southern France ( $P$. ferreri Bondroit, 1918 may also be present in the French part of the Pyrenees).

Proformica nasuta is the type species for the genus Proformica and was described from Beaucaire, France. The concept of this species is unclear. For instance, variation in the number of erect hairs on the mesosoma, a character commonly used in the taxonomy of Proformica, has been interpreted either as mere intraspecific variation (Espadaler \& Cagniant 1987), or as an indication that the name P. nasuta actually covers two taxa (Santschi 1925; Collingwood \& Yarrow 1969). Populations of species of Proformica are small, inconspicuous and patchily distributed, and the species are often considered rare. As a consequence, the genus is poorly represented in institutional collections and most taxonomic work is based on few specimens, rendering the accurate perception of intra-specific variation difficult. Moreover, the type specimen of P. nasuta has not been located. Having not been found in the most likely candidate collections and not explicitly referred to in the literature, it is presumably lost. As $P$. nasuta is the oldest name in the genus, designation of a neotype and a precise redefinition of this taxon are indispensable before further taxonomic work on this genus can be undertaken. For this purpose, we analysed a sample, unprecedented in its size and geographic extent, of Proformica nests in southern France using an integrative taxonomy approach based on morphological data from workers and sexuals, DNA sequences and cuticular hydrocarbons. Southern France was the best location for this investigation as it encompasses the type locality for P. nasuta and harbours no other known Proformica species. Combining the results of these different characters can increase our ability to provide valid decisions about species delimitations (Schlick-Steiner et al. 2010). Although some of these kinds of data are less relevant than others for the descriptive taxonomy of a particular species group, incongruences between results based on different kinds of data can provide information on the biology of the group studied and insights into ongoing ecological and evolutionary processes. 


\section{Material and methods}

\section{Sampling}

We sampled 110 nests of Proformica at 22 localities from across southern France (Fig. 1), including four nests at the type locality of $P$. nasuta (Beaucaire) and seven nests less than $10 \mathrm{~km}$ from that site. Collection details for each nest are provided in Appendix 1. We give here a more detailed description of the collection localities. Fourteen sites (Aurons, Beaucaire, Bonnieux, Collias, Plaine de la Crau, Grospierres, Jonquières, Montpellier, Orange, Pompignan, Sauteyrargues, Sisteron, Tarascon, Vinsobre) were found in lowland Mediterranean garrigue or sun-exposed grassland. Nests were usually found in areas where soil had been heavily trampled. Four sites (Grand Luberon, Montagne de Lure, SainteBaume, Sumène) were on rocky summits of medium-sized calcareous mountains with little vegetation cover. Finally, four sites (Plateau de Calern, Plateau de Caussols, Gréolières, Mont Ventoux) were on mountain slopes or plateaus in the foothills of the Alps, also bearing little vegetation cover.

\section{Morphological investigation}

Most of the morphological characters used were introduced by Seifert (2007).

Eight morphological characters were measured on 321 worker individuals originating from 97 nests collected at 21 localities (Appendix 1). Colonies are monodomous, so each nest represents one colony. Mean values were calculated for worker individuals collected from each nest (range 1-8, mean 3.3 workers per nest).

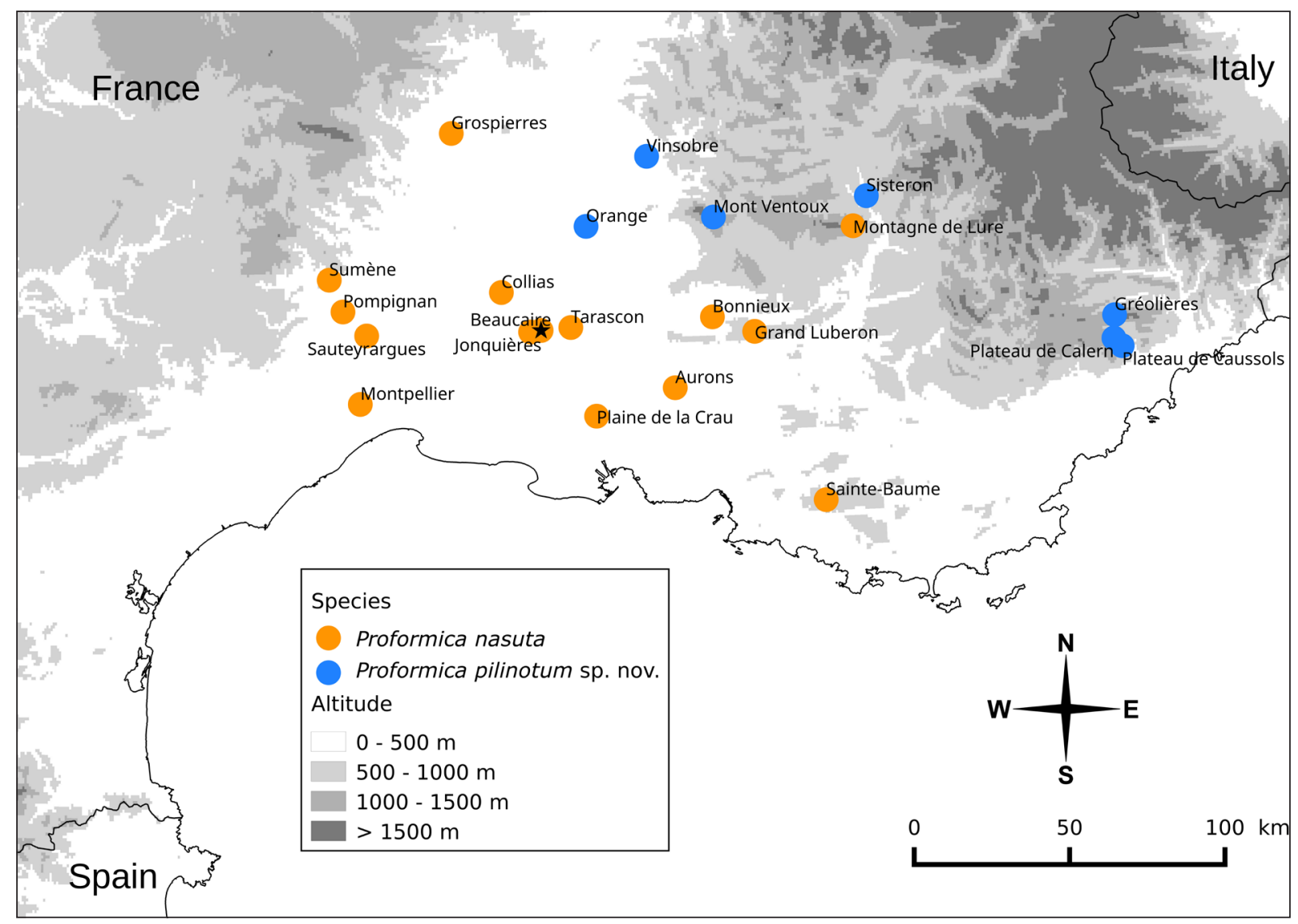

Fig. 1. Distribution of the 22 localities where Proformica nest samples were collected. The star indicates the type locality of Proformica nasuta (Nylander, 1865) (i.e., Beaucaire). 
Morphometric characters measured:

$\mathrm{CW}=$ Maximum cephalic width (including eyes) (in $\mu \mathrm{m}$ )

$\mathrm{GHL}=$ Length of the longest erect seta on the gaster (in $\mu \mathrm{m})$

$\mathrm{nCH}=$ Unilateral number of erect setae on the vertex

$\mathrm{nCU}=$ Unilateral number of erect setae on the underside of the head

$\mathrm{nG}=$ Unilateral number of erect setae on the gaster

$\mathrm{nSc}=$ Unilateral number of erect setae on the petiole

$\mathrm{nTx}=$ Unilateral number of erect setae on the mesosoma

$\mathrm{PDG}=$ Pubescence distance on dorsum of the first gaster tergite, computed as $\mathrm{L} / \mathrm{N}$, where $\mathrm{N}$ is the number of pubescent (appressed) hairs crossing a transverse line of length L; here we used a line of length $340 \mu \mathrm{m}$

Ten queens from six localities (Beaucaire, Orange, Sainte-Baume, Pompignan, Tarascon, Mont Ventoux) were measured for 14 characters:

$\mathrm{ML}=$ Mesosoma length (in $\mu \mathrm{m})$

$\mathrm{MW}=$ Mesosoma width (in $\mu \mathrm{m}$ )

nMes $=$ Unilateral number of erect setae on the scutum and scutellum, or on the mesonotum if scutum and scutellum were not discernible

$\mathrm{nPn}=$ Unilateral number of erect setae on the pronotum

$\mathrm{nPP}=$ Unilateral number of erect setae on the propodeum

$\mathrm{ScW}=$ Width of petiole scale (in $\mu \mathrm{m})$

$\mathrm{SL}=$ Scape length (in $\mu \mathrm{m})$

$\mathrm{CW}, \mathrm{nCH}, \mathrm{nCU}, \mathrm{nSc}, \mathrm{nG}, \mathrm{PDG}$ and GHL: see worker morphology.

Measurements of workers and queens are given below (Appendices 2-3).

We collected a total of 11 males from three localities (Plaine de la Crau, Pompignan and Tarascon) and examined males from Sainte-Baume that had been collected by F. Bernard (MNHN) in July 1974. Males were only described qualitatively.

Acronyms of depositories:

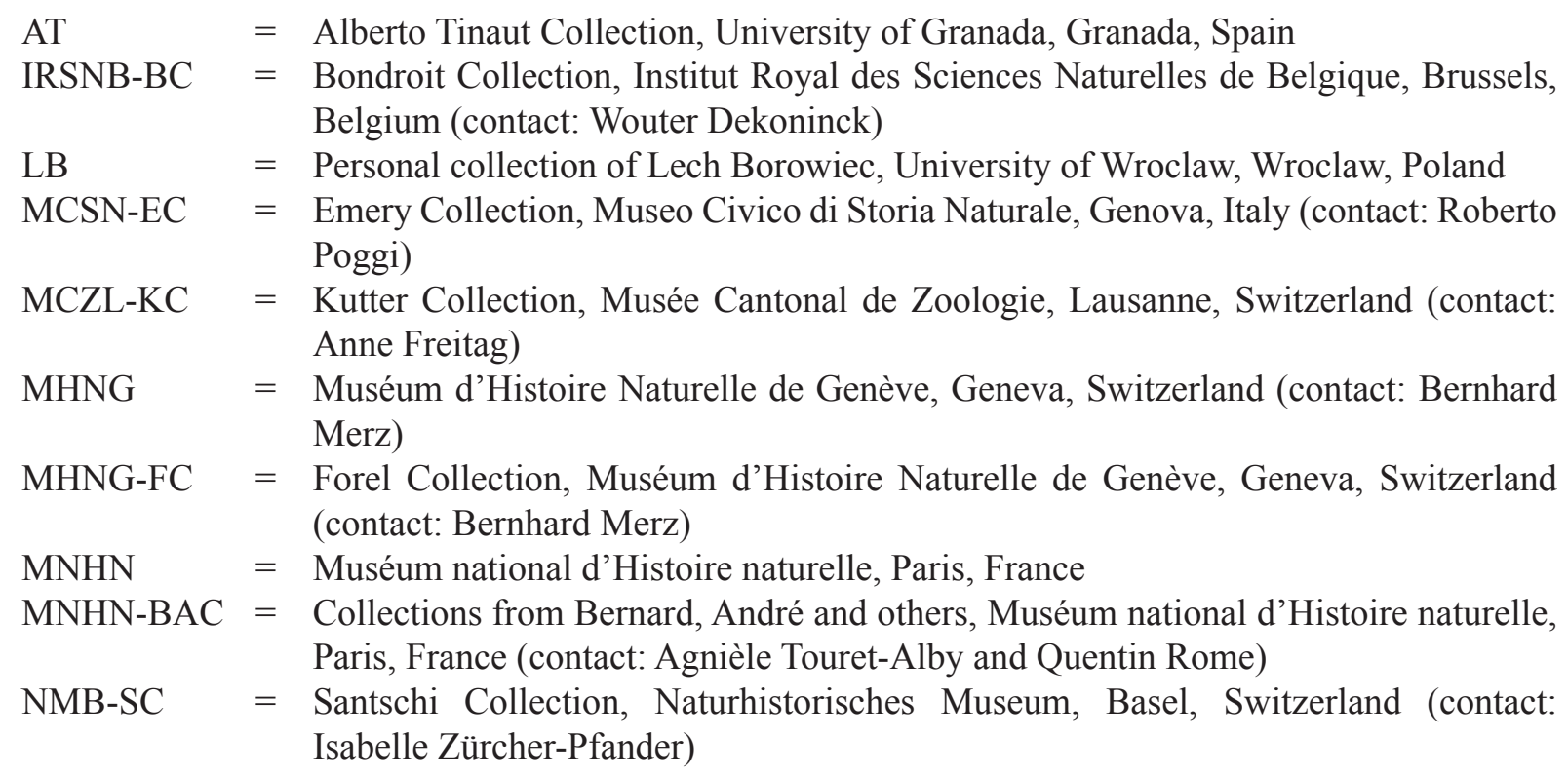




$\begin{array}{ll}\text { SMNH } & \text { Senckenberg Museum of Natural History, Görlitz, Germany } \\ \mathrm{XE} & = \\ & \text { Personal collection of Xavier Espadaler (Autonomous University of Barcelona, } \\ \text { ZISP } & \text { Zoological Institute of Russian Academy of Sciences, St. Petersburg, Russia }\end{array}$

\section{Molecular phylogenetic analysis}

DNA was extracted from 1-2 individuals from each of 98 nests distributed in 20 localities (Appendix 1), using the REDExtract-N-Amp PCR Kit (Sigma-Aldrich, St. Louis, MO). Amplification by polymerase chain reaction (PCR) was performed using either the Goldstar Red DNA Polymerase (Eurogentec), the Qiagen Multiplex kit (Qiagen, Venlo, Netherlands) or the Sigma REDExtract-N-Amp PCR Ready Mix (Sigma-Aldrich). Conditions for PCR first followed manufacturer's instructions, and were then adjusted if amplification failed. Sanger sequencing of PCR products was performed at the Genoscope (Evry, France).

We amplified four DNA markers, two mitochondrial, two nuclear: (i) COI ( $\sim 600 \mathrm{bp})$, coding for part of the cytochrome c oxydase subunit 1, (ii) Cytb ( $700 \mathrm{bp})$, corresponding to the end of the sequence coding for NADH dehydrogenase subunit 6 and part of cytochrome b, (iii) $28 \mathrm{~S}$ ( $\sim 600 \mathrm{bp}$ ), coding for part of the large ribosomal subunit, and (iv) LW Rh ( $\sim 550 \mathrm{bp})$, coding for part of the long-wavelength rhodopsin. COI was amplified for 45 Proformica individuals (GenBank accession numbers: KU749600KU749637 and KU749641-KU749654) using two sets of primers covering the same region: either LepF1 (5'-ATTCAACCAATCATAAAGATAT-3') and LepR1 (5'-TAAACTTCTGGATGTCCAAAAA-3') (Hebert et al. 2004), or CI13 (5'-ATAATTTTTTTTATAGTTATACC-3') and CI14 (5'-ATTTCTTTTTTTCCTCTTTC-3') (Hasegawa et al. 2002). For some individuals we used the two different primer pairs and compared the sequences obtained for the same individual. For each of four individuals, two highly divergent copies of COI were sequenced. To detect sequences that might come from accidental amplification of numts (copies of mitochondrial DNA transferred into the nuclear genome), we searched for the presence of premature stop codons in the amino-acid sequences. Three sequences (belonging to two individuals) had one premature stop codon. Based on the distribution of these sequences and the divergent copies from the same individual in the COI phylogeny, we identified a clade of putative numts. We amplified the Cytb marker using primers Cytb-FeF (5'-CAGTTTAATTTCTAATGAACAAAC-3') and Cytb-FeR(5'-GGATCTCTAAAAATATATGGG-3') (Liautard \& Keller 2001) for a subset of Proformica individuals, and we used these sequences to design internal primers more specific to Proformica in order to increase amplification success: cytbPf (5'-CCTTTTAATAATRTYACTATTGC-3') and cytbPr (5'- TATAARTTTCTATTAATTCCAAG-3'). In total we amplified the Cytb marker in 103 individuals of Proformica (GenBank accession numbers: KU749655-KU749737 and KU749739-KU749758). The 28S marker was amplified for 31 individuals of Proformica (GenBank accession numbers: KU749759-KU749783 and KU749788KU749793) using primers D2B (5'-GTCGGGTTGCTTGAGAGTGC-3') (Saux et al. 2004) and D2R (5'-TTGGTCCGTGTTTCAAGACGGG-3') (Belshaw \& Quicke 1997). The LW Rh marker was amplified for 31 individuals of Proformica (GenBank accession numbers: KU749794-KU749818 and KU749823-KU749828) using primers LR143F (5'-GACAAAGTKCCACCRGARATGCT-3') and LR639ER (5'-YTTACCGRTTCCATCCRAACA-3') (Ward \& Downie 2005). DNA sequences were aligned with MUSCLE (Edgar 2004). Alignments were inspected visually and edited manually using MEGA5 (Tamura et al. 2011) when they could be improved. Alignment of the intergenic region in the Cytb marker was ambiguous, and thus removed from the analysis.

As outgroup we used species for which we obtained new sequences (Appendix 1): Bajcaridris theryi (Santschi, 1936) (GenBank accession numbers, 28S: KU749786, LW Rh: KU749821), Cataglyphis cursor (Fonscolombe, 1846) (GenBank accession numbers, COI: KU749638 and KU749640, Cytb: KU749738, 28S: KU749787, LW Rh: KU749822), Cataglyphis mauritanica (Emery, 1906) (GenBank 
accession numbers, COI: KU749639, 28S: KU749785, LW Rh: KU749820), Formica cunicularia Latreille, 1798 (GenBank accession numbers, 28S: KU749784, LW Rh: KU749819), and species for which sequences were retrieved from GenBank (Hasegawa et al. 2002; Goropashnaya et al. 2004, 2007, 2012; Ward \& Downie 2005; Moreau et al. 2006): Cataglyphis iberica (Emery, 1906) (COI: DQ353343), Formica cunicularia (COI: AB010926), Formica exsecta Nylander, 1846 (COI: AB010927, Cytb: JX170868), Formica pratensis Retzius, 1783 (Cytb: AY584233), Formica rufibarbis Fabricius, 1793 (Cytb: JX170889), Formica truncorum Fabricius, 1804 (COI: AB010929), Formica uralensis Ruzsky, 1895 (Cytb: JX170879), Formica wheeleri Creighton, 1935 (28S: DQ353556, LW Rh: DQ353149).

A partition scheme was defined with PartitionFinder (Lanfear et al. 2012) for each phylogenetic analysis, using the Bayesian Information Criteria for nucleotide substitution model selection. Prior data blocks were defined by marker and codon position. Three separate phylogenetic reconstructions were performed using both maximum likelihood and Bayesian inference algorithms: one for COI (to highlight the position of the clade of putative numts), one for Cytb (which includes the largest number of individuals), and one for the concatenated nuclear markers (28S + LW Rh) (because nuclear and mitochondrial markers might tell different stories).

Maximum likelihood phylogenies were constructed with RAxML (Stamatakis et al. 2008) on the web server at vital IT, Switzerland (http://embnet.vital-it.ch/raxml-bb/), using the GAMMA model of rate heterogeneity. Node support was estimated by generating 100 trees by bootstrapping. Bayesian inference phylogenies were constructed with MrBayes 3.2 (Ronquist et al. 2012). For the COI phylogeny we used the substitution models $\mathrm{SYM}+\mathrm{G}, \mathrm{F} 81$ and GTR $+\mathrm{G}$ for the first, second and third codon position, respectively. For Cytb we used $\mathrm{HKY}+\mathrm{G}, \mathrm{HKY}+\mathrm{I}$ and $\mathrm{GTR}+\mathrm{I}+\mathrm{G}$ for the first, second and third codon position respectively. For the concatenated nuclear genes we used K80 for the first codon position of $\mathrm{LW} \mathrm{Rh}$, and $\mathrm{K} 80+\mathrm{I}$ for $28 \mathrm{~S}$ and the second and third codon positions of LW Rh. Each analysis consisted of two runs of four Markov chains run for 10 million generations. Parameters were unlinked for all partitions. A standard deviation of split frequencies of less than 0.01 between two independent runs was reached after less than 2.4 million generations. A burn-in fraction of the first $25 \%$ of the trees was discarded.

\section{Cuticular hydrocarbons}

Colonies from nine localities (Bonnieux, Plaine de la Crau, Montpellier, Grand Luberon, Montagne de Lure, Sainte-Baume, Pompignan, Sisteron, Mont Ventoux) were used for analysis of cuticular hydrocarbons. Using forceps, we gathered three to five workers from each colony and put them into glass vials containing $1 \mathrm{ml}$ of hexane. The containers were stored in a freezer at $-20^{\circ} \mathrm{C}$ until chemical analysis. For chemical analysis, the ants were retrieved from the vials and the solvent evaporated. The extract was re-dissolved in $10 \mu \mathrm{l}$ of hexane. Two $\mu \mathrm{l}$ of each extract were injected into a Perkin-Meyer GC-MS functioning at $70 \mathrm{eV}$ with a source temperature of $230^{\circ} \mathrm{C}$ and equipped with a ZB-5HT column $(30 \mathrm{ml} \times 0.25 \mathrm{~mm}$ ID $\times 0.252 \mu \mathrm{m} \mathrm{df} ; 5 \%$ phenyl- $95 \%$ dimethylpolysiloxane). The temperature program was $2 \mathrm{~min}$ at $150^{\circ} \mathrm{C}$, and then $5^{\circ} \mathrm{C} / \mathrm{min}$ until $320^{\circ} \mathrm{C}$, and a $5 \mathrm{~min}$ hold at $320^{\circ} \mathrm{C}$ (total $41 \mathrm{~min}$ ). Substances were identified using standard alkanes, library data and Kovats retention indices. For the comparisons, we calculated the percentage of each hydrocarbon from the total hydrocarbon content in each ant sample. The data were analysed using Principal Component Analysis. We chose not to transform the data since transformation introduces additional background noise into the data when numerous zero values are present; these have to be replaced to make transformation possible when comparing species. Indeed, reanalysis of the data after transformation (following the procedure of Reyment 1989) gave similar results, but with slightly less efficient separation of groups (Oppelt et al. 2008). Analyses were made with the Statistica software. 
We also performed chromatograms of cuticular hydrocarbons for two species used as outgroups: Proformica longiseta Collingwood, 1978 from Sierra Nevada (Spain) and Cataglyphis cursor from Aixen-Provence (France). Lists of cuticular hydrocarbons known for these species have been published in Errard et al. (2006) and Nowbahari et al. (1990), respectively, but without quantification.

\section{Nest census and queen reproductive status}

Six nests were excavated in July 2011 and the ants counted. Six queens from two nests were dissected to assess their reproductive status. In addition, one apterous queen was obtained by rearing pupae from Sainte-Baume and was dissected to confirm its queen status. Several workers of various sizes were also dissected.

\section{Results}

\section{Morphology and altitudinal distribution}

Two groups of nests were separated by combining two morphological characters, GHL and PDG for the workers, and GHL and nG for the queens (Fig. 2). The two groups were distinct for both characters, independently of CW, a proxy for size (Fig. 2). One of the groups, coloured in orange in the figures and hereafter denominated as the orange taxon, encompasses the type locality of Proformica nasuta (Fig. 1). The other group is coloured in blue in the figures and is hereafter denominated as the blue taxon. Workers of the orange group present denser pubescence, shorter erect hairs on the gaster and fewer erect hairs (or none) on the mesosoma (PDG $<29$, GHL $<77 \mu \mathrm{m}$, nest means, $\mathrm{nTx} \times 2 \pm \mathrm{SD}=9.5 \pm 10.4$ ) than those of the blue group ( $\mathrm{PDG}>33$, GHL $>85 \mu \mathrm{m}$, nest means, $\mathrm{nTx} \times 2 \pm \mathrm{SD}=46.8 \pm 16.7$ ).

Further, queens of the blue taxon were all winged or showed wing sclerites, while all queens of the orange taxon were ergatoid. We did not find males of the blue taxon in the field and we could not locate specimens in museum collections. Males of the orange taxon have dense and long hairs on the head, mesosoma and the anterior face of the first gaster segment.

For both the orange taxon and the blue taxon, altitudinal distribution of the nests was bimodal (Fig. 3). Most nests of the orange taxon were found below $200 \mathrm{~m}$, but those from Sainte-Baume, Sumène, Grand Luberon and Montagne de Lure were found above $800 \mathrm{~m}$, at the tops of medium-sized mountains. In contrast, most nests of the blue taxon were found above $1000 \mathrm{~m}$ on plateaus and mountains, but those from Orange, Sisteron and Vinsobre were found lower, below $600 \mathrm{~m}$. Interestingly, within each of these taxa, GHL and PDG are highest for workers from the mountain localities (except for Sumène) (Fig. 2).

\section{Molecular phylogenetic analysis}

Maximum likelihood and Bayesian inference produced very similar phylogenies, so we chose to present only Bayesian inference phylogenies. The clade of putative numts in the COI phylogeny is delimited in red in Fig. 4A. The two mitochondrial markers yielded similar topologies (Fig. 4A-B), showing two main clades which corresponded approximately to the two taxa defined in the morphological analysis. Mismatch between morphotypes and clades was observed for some specimens. The nuclear markers showed very little variation. As a consequence, the resulting tree is poorly resolved (Fig. 4C).

\section{Cuticular hydrocarbons}

Identification of compounds and examples of chromatograms are included below (Appendices 4-5). Chromatograms showed very different profiles. Most hydrocarbons of the blue taxon are shorter $(<\mathrm{C} 28)$ than those of the orange taxon $(>\mathrm{C} 28)$. Two forms can be distinguished in the orange taxon: the lowland localities, in which individuals have the longest hydrocarbons (> C31), and the mountain localities (Montagne de Lure and Grand Luberon), where the hydrocarbons are of an intermediate length 

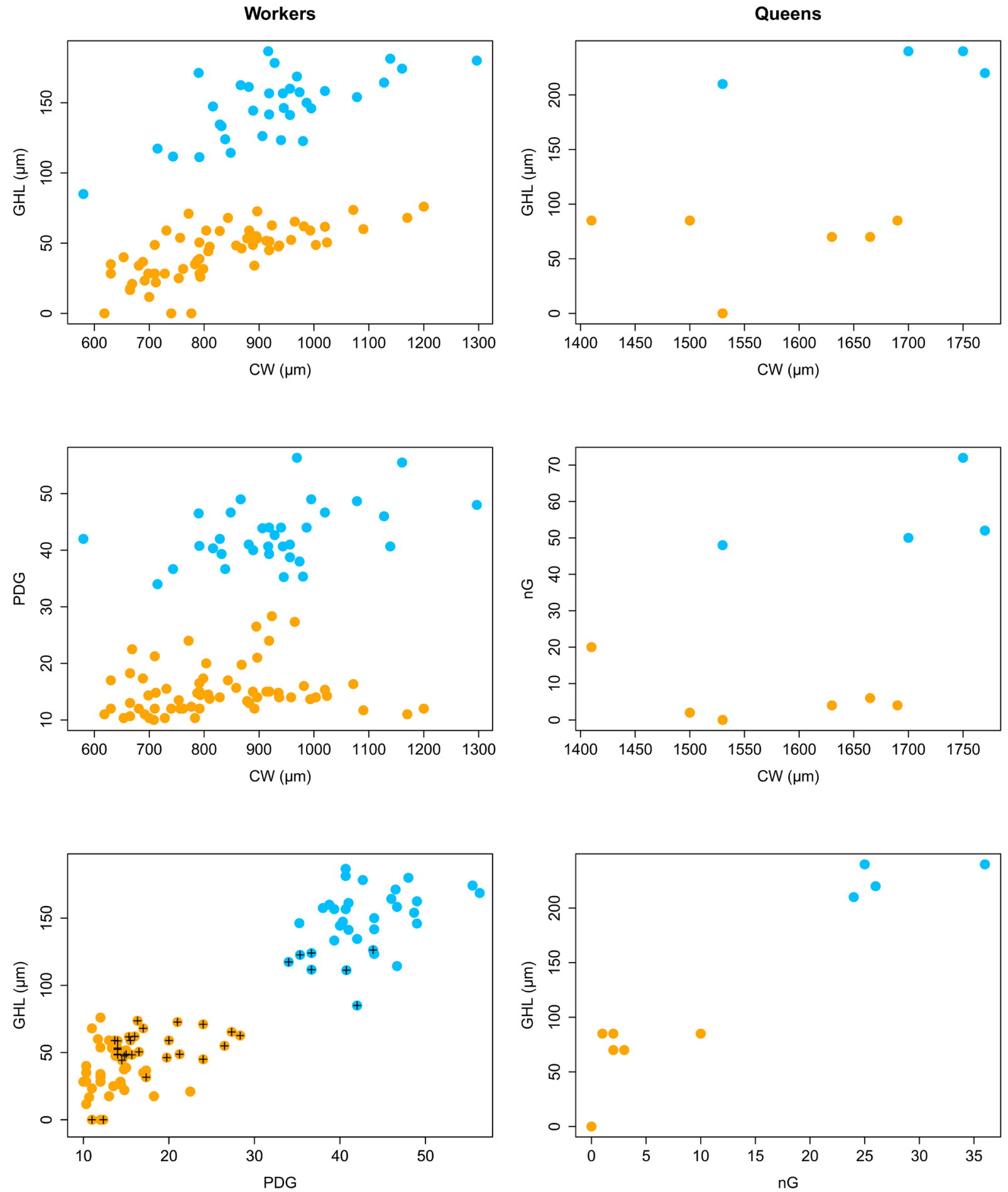

Fig. 2. Distribution of morphological characters of Proformica workers (left) and queens (right) collected in southern France. Top and middle graphics represent the regression of gaster hair length (GHL), pubescence distance on the gaster (PDG) and unilateral number of hairs on the gaster (nG) against cephalic width $(\mathrm{CW})$, a proxy for size. The graphics at the bottom represent a combination of two morphological characters that highlights two distinct groups of nests. These two groups are coloured in blue and orange respectively. The dots with a black cross correspond to nests from mountain and lowland localities for the orange and blue groups, respectively. 
(Appendix 5). The PCA distinguishes the two outgroups, Proformica longiseta and Cataglyphis cursor, from the Proformica samples from southern France (Fig. 5). The blue and orange taxa are segregated along the first axis of the PCA. In addition, the strongest differentiation occurs within the orange taxon, between a group formed by the two mountain localities (Montagne de Lure and Grand Luberon) and the others.

\section{Queen reproductive status, nest census}

Excavation of nests of the two taxa revealed the same general structure: the entrance opens directly at the ground surface, sometimes under a small stone; a vertical gallery of 10-20 cm leads to a small chamber where males can be found when present; then, the gallery goes down obliquely and reaches a final chamber, about $50 \mathrm{~cm}$ below ground level, where queens are present. Secondary galleries, lateral (perpendicular) to the principal one, may be present and lead to chambers. The content of nests is presented in Table 1. Repletes, i.e. workers with inflated gaster serving as stores of liquid food, were
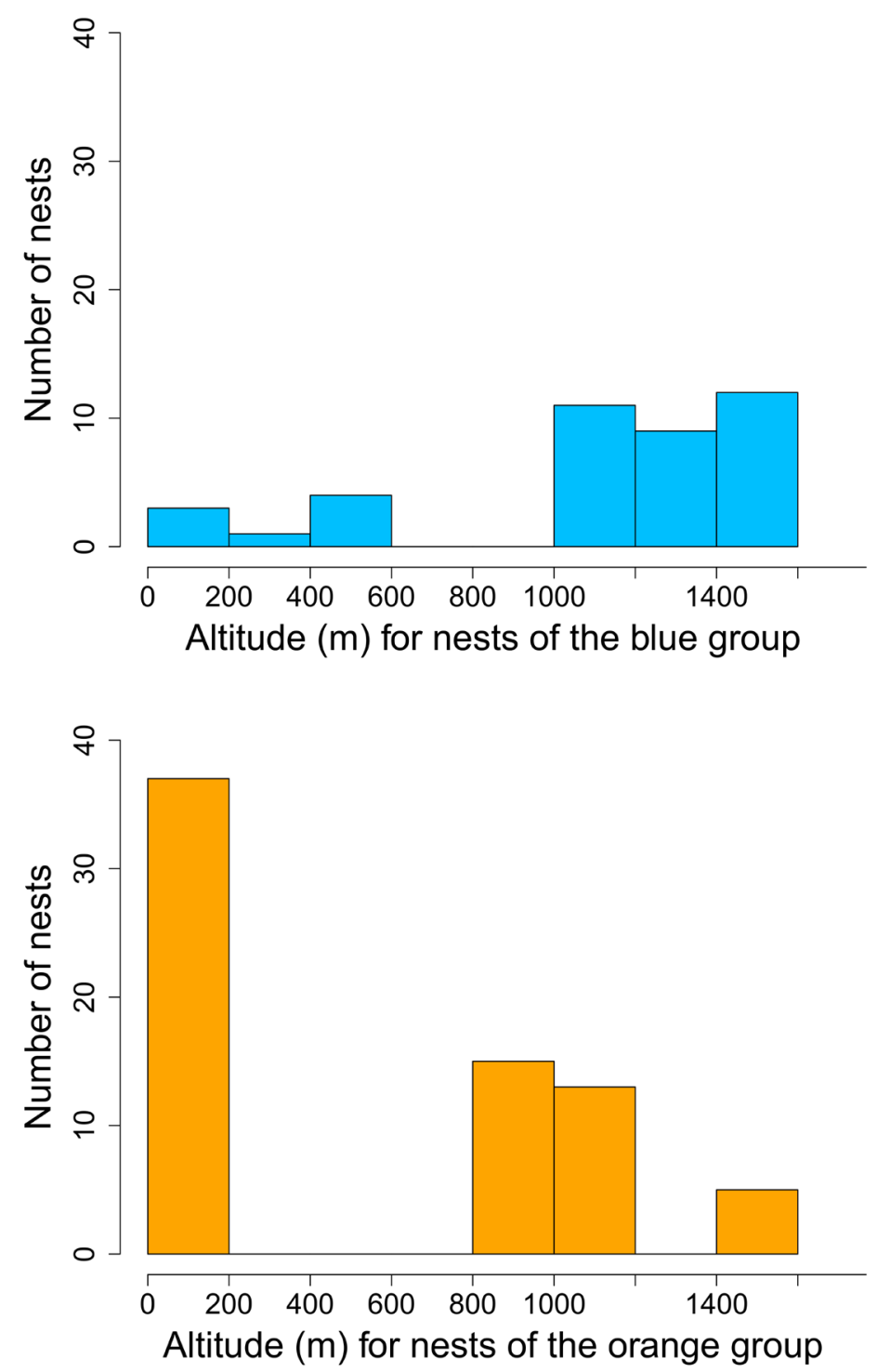

Fig. 3. Altitudinal distribution of 110 nests of Proformica from southern France belonging to two morphological groups. 
found in colonies of both taxa. Colonies had one to many queens that appeared to be actively reproducing (mated, with numerous mature oocytes and yellow bodies) (Table 2). Workers, even the largest, always had fewer than 3 ovarioles per ovary and never had a spermatheca. In contrast, apterous and winged queens had a spermatheca and many more ovarioles per ovary $(\sim 10)$.
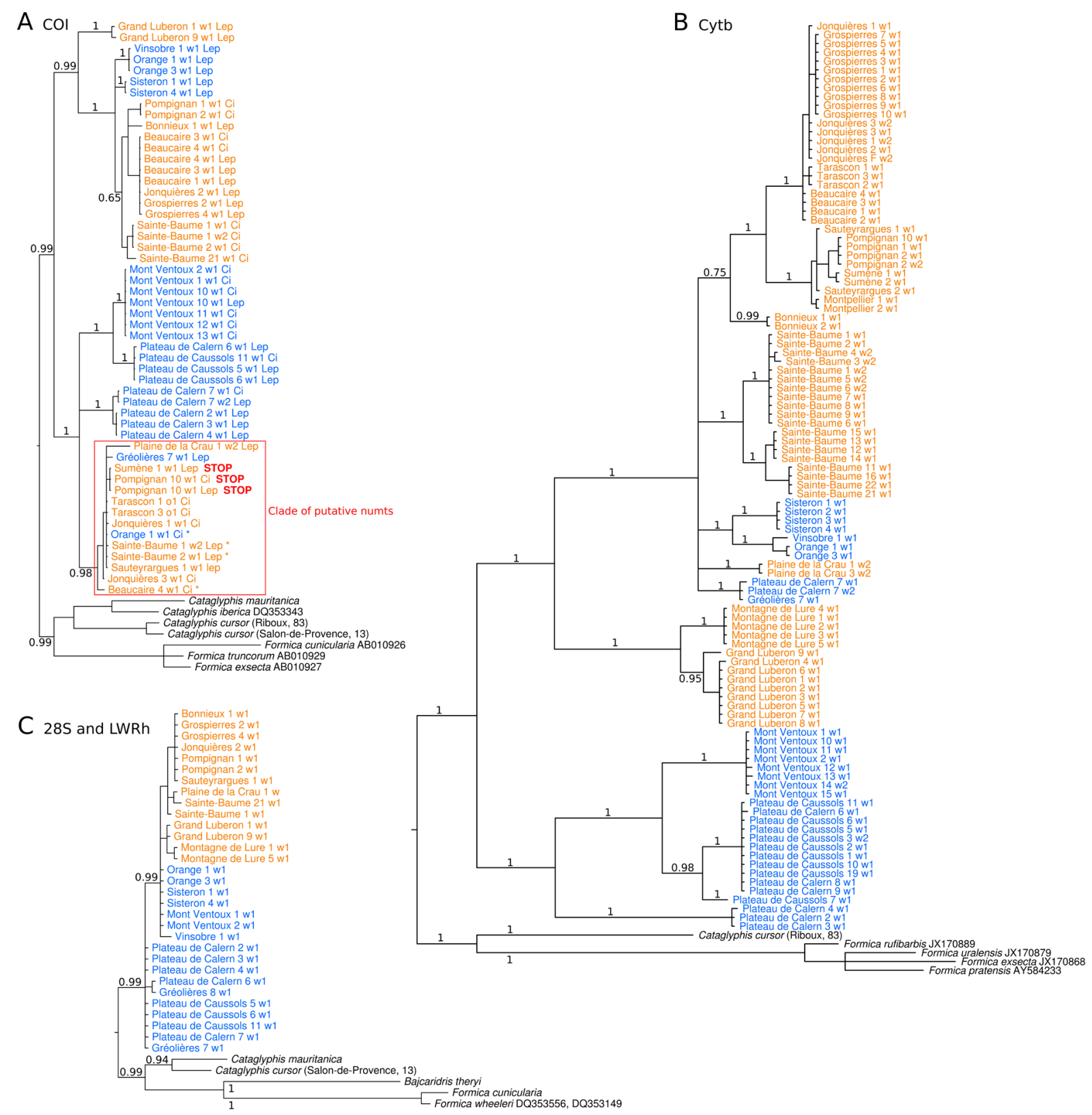

Fig. 4. Bayesian consensus trees of COI (A), Cytb (B) and concatenated sequences of $28 \mathrm{~S}$ and LW Rh (C) for Proformica workers from southern France and outgroups. Labels are composed of the locality name, the colony code (figure), the code of the individual (w1 for worker 1, w2 for worker 2) and, for COI, the primer pair used (Ci for CI13 and CI14, Lep for LepF1 and LepR1). Sequences where a stop codon was detected are labelled with a red "STOP". Sequences with an asterisk specify individuals for which another sequence was obtained and fitted outside the clade of putative numts. Colours match the groups defined in the morphological analysis. Posterior probabilities are given for major nodes. Accession numbers are indicated for sequences retrieved from GenBank. 


\section{Taxonomy}

Class Hexapoda Blainville, 1816

Order Hymenoptera Linnaeus, 1758

Superfamily Vespoidea Latreille, 1802

Family Formicidae Latreille, 1809

Subfamily Formicinae Latreille, 1809

\section{Proformica Ruzsky, 1902}

Nylander (1856) described P. nasuta, the type species of the genus, from Beaucaire. Our analyses assigned workers from the type locality and from two other localities within a radius of $10 \mathrm{~km}$ (Jonquières and Tarascon) to the orange taxon. They lack erect hairs on the mesosoma, agreeing with the description of Proformica nasuta by Nylander as "nuda". Although the type is presumably lost (as it could not be found in the following collections: Nylander (Helsinki) (Radchenko 2007), Forel (Geneva), Emery (Genoa), Bondroit (Brussels) and Santschi (Basel)), we are confident that the nest samples we collected in Beaucaire and in the surrounding area correspond to the species described by Nylander. Below we provide a redescription of $P$. nasuta (the orange taxon), and the description of a new species, P. longipilosa sp. nov. (the blue taxon).

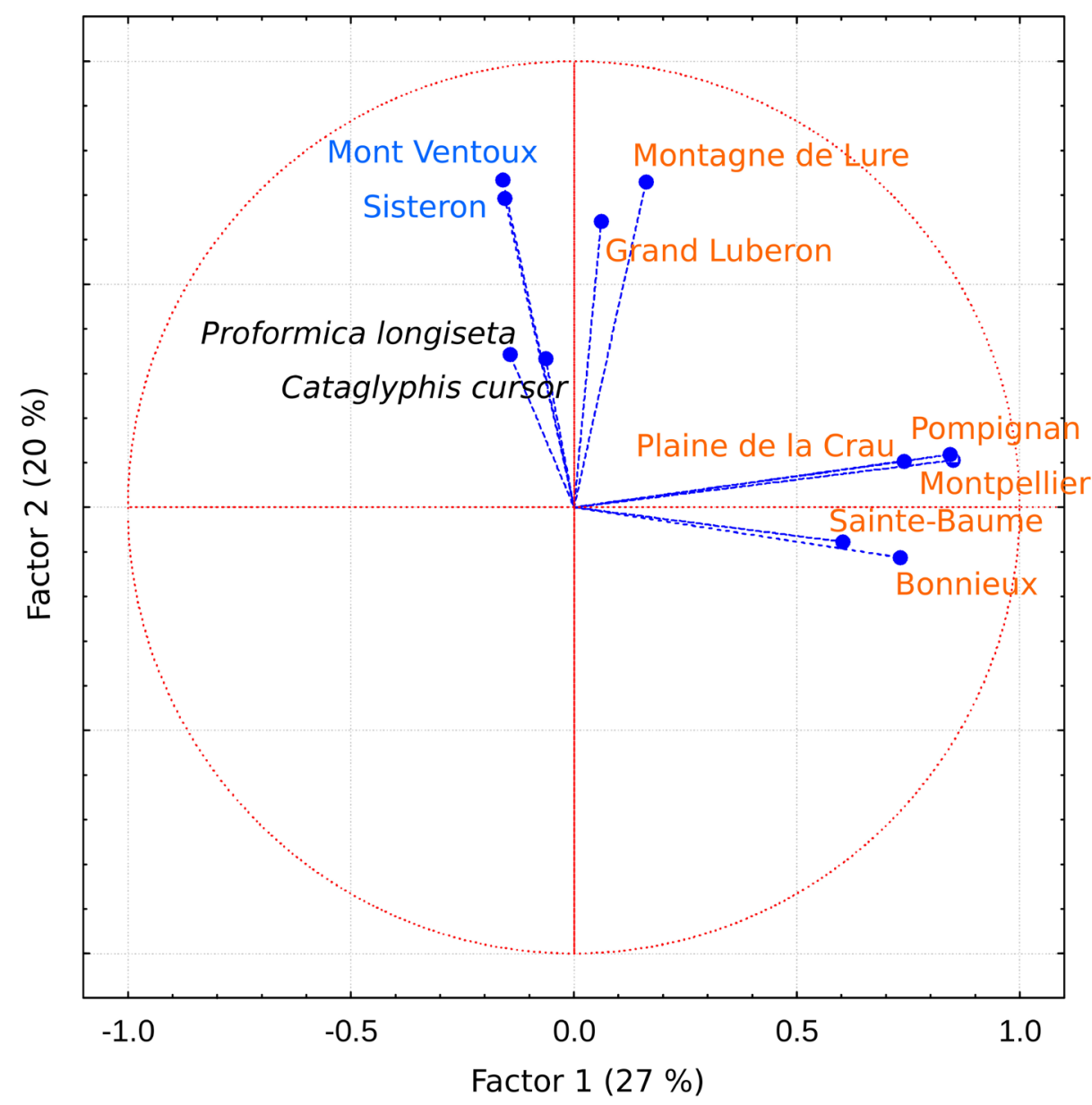

Fig. 5. Principal Component Analysis of Proformica localities based on relative proportions of cuticular hydrocarbons identified by gas chromatography and mass spectrometry. Colours match the groups defined in the morphological analysis. 

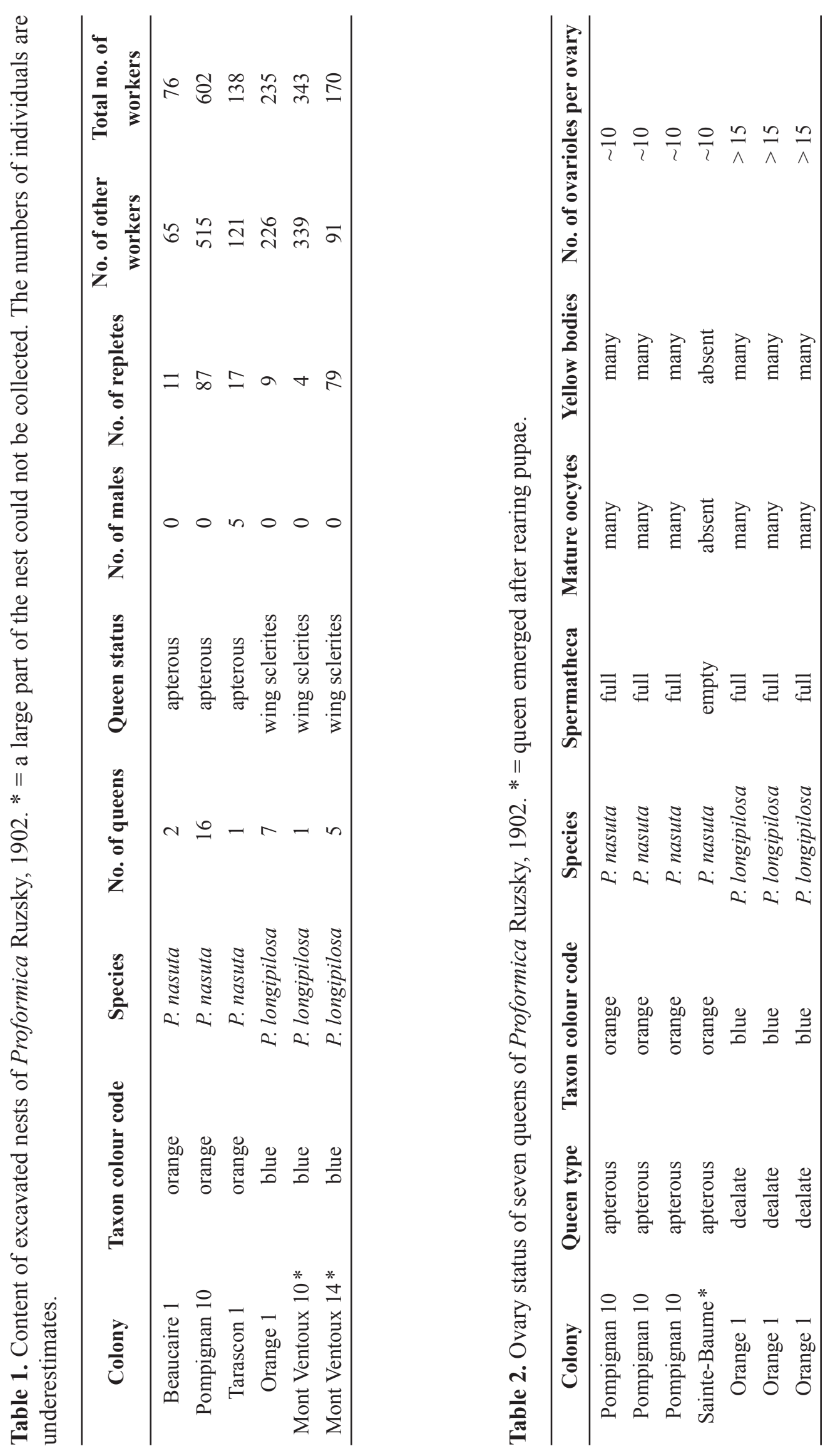


\section{Redescription of P. nasuta (Nylander, 1856) and designation of the neotype}

As the type specimen of $P$. nasuta is presumably lost, we propose fixation of a neotype from a nest sample collected in Beaucaire, France, terra typica of the species, and matching Nylander's concept of P. nasuta. The original description (Nylander 1856: 66) is based on a small worker ("Long. $3-3.5 \mathrm{~mm}$ ") with elongated head ("... facies producta antice visa subrectangularis..."). This feature is found exclusively in minor workers. Therefore, a minor worker was selected from Beaucaire, France (colony Beaucaire 1) and designated as the neotype. The neotype is deposited as MNHN-1598 with the labels "FRA, N43.83544 E4.61828, Beaucaire, 9 juillet 2011, leg. R. Blatrix \& C. Lebas" and "Néotype Proformica nasuta (Nylander, 1856), des. Galkowski, Lebas, Wegnez, Lenoir \& Blatrix, 2016". In case of loss or destruction of this specimen, a replacement neotype can be designated from a series of ten other minor workers collected from the same nest and deposited at the MNHN. Other workers from the same nest are deposited at the following collections: AT (no. 15557), LB, SMNH, XE, ZISP and the collections of the authors. A queen from the same nest and a male from colony Tarascon 1 (a few kilometers away from the type locality) are deposited at MNHN.

Proformica nasuta (Nylander, 1856)

Figs 6-8

Formica nasuta Nylander, 1856: 66.

Formica (Proformica) nasuta var. depilis Santschi, 1925: 353.

\section{Material examined}

Museum material

FRANCE: MHNG: Charleval, Bouches-du-Rhône, leg. E. della Santa, labelled P. nasuta, 11 Jul. 1987: 4 workers, 25 Jul. 1988: 3 workers. - NMB-SC: Carrière des Anglais, Vaucluse: 2 workers, types of Formica (Proformica) nasuta var. depilis. - MNHN-BAC: Sainte-Baume, 90 workers (12 pins), 3 ô ô, one of which labelled "Type phoenica" [Proformica phoenica is a nomen nudum, as it was never described by Bernard. Proformica ants at this locality form a mountain isolate which most probably derived from lowland populations of P. nasuta; see Discussion]. - IRSNB-BC: $2 \hat{\jmath}$, without locality.

\section{New material}

FRANCE: All in personal collections of CF and RB: Aurons, 4 workers, $43.66^{\circ} \mathrm{N}, 5.15^{\circ} \mathrm{E}$, Jun. 2006, leg. V. Bouchet; Beaucaire, 14 workers, 2 queens, $43.8354^{\circ} \mathrm{N}, 4.6187^{\circ} \mathrm{E}, 9 \mathrm{Jul} .2011$, leg. R. Blatrix and C. Lebas; Bonnieux, 8 workers, $43.8625^{\circ} \mathrm{N}, 5.3069^{\circ} \mathrm{E}, 1$ Oct. 2011, leg. C. Lebas; Collias, 5 workers, $43.9477^{\circ}$ N, $4.4623^{\circ}$ E, 12 Jun. 2010, leg. R. Blatrix; Plaine de la Crau, Saint-Martin-de-Crau, 18 workers, $1 \mathrm{o}^{\top}, 43.5833^{\circ} \mathrm{N}, 4.8333^{\circ} \mathrm{E}$, Jun. and Aug. 2011, leg. C. Lebas; Grospierres, 30 workers, $44.4116^{\circ} \mathrm{N}$, $4.2713^{\circ} \mathrm{E}$, 6 Jul. 2012, leg. T. Colin; Jonquières-Saint-Vincent, 7 workers, $43.8314^{\circ} \mathrm{N}, 4.5765^{\circ} \mathrm{E}$, 11 May 2011, leg. R. Blatrix; Montpellier, 3 workers, 43.6292 ${ }^{\circ}$ N, $3.8907^{\circ}$ E, 8 Mar. 2012, leg. R. Blatrix; Pompignan, 3 workers, 5 queens, $2{ }^{\wedge} \partial^{\wedge}, 43.8979^{\circ} \mathrm{N}, 3.8252^{\circ} \mathrm{E}$, May 2010 and $10 \mathrm{Jul} .2011$, leg. R. Blatrix and P. Wegnez; Sauteyrargues, 4 workers, $43.8275^{\circ}$ N, $3.9192^{\circ}$ E, 28 May 2011, leg. R. Blatrix; Sumène, 6 workers, $43.9904^{\circ}$ N, 3.7714 E, 9 Apr. 2014, leg. R. Blatrix; Tarascon, 12 workers,

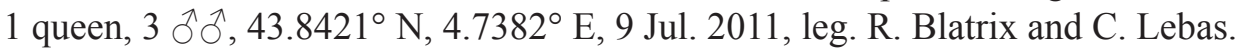

\section{Description}

Minor worker $(\mathrm{n}=89)$

For each character extreme values and the mean are given in brackets:

CW 540-900 $\mu \mathrm{m}$; nCH 0-2 (0.06); nCU 0-3 (0.18); nTx 0-6 (0.57); nSc 0-2 (0.13); nG 0-5 (1); PDG 9-28 (13.2); GHL 35-75 $\mu \mathrm{m}$ (45.2); GHL/CW 0.040-0.102 (0.064). 

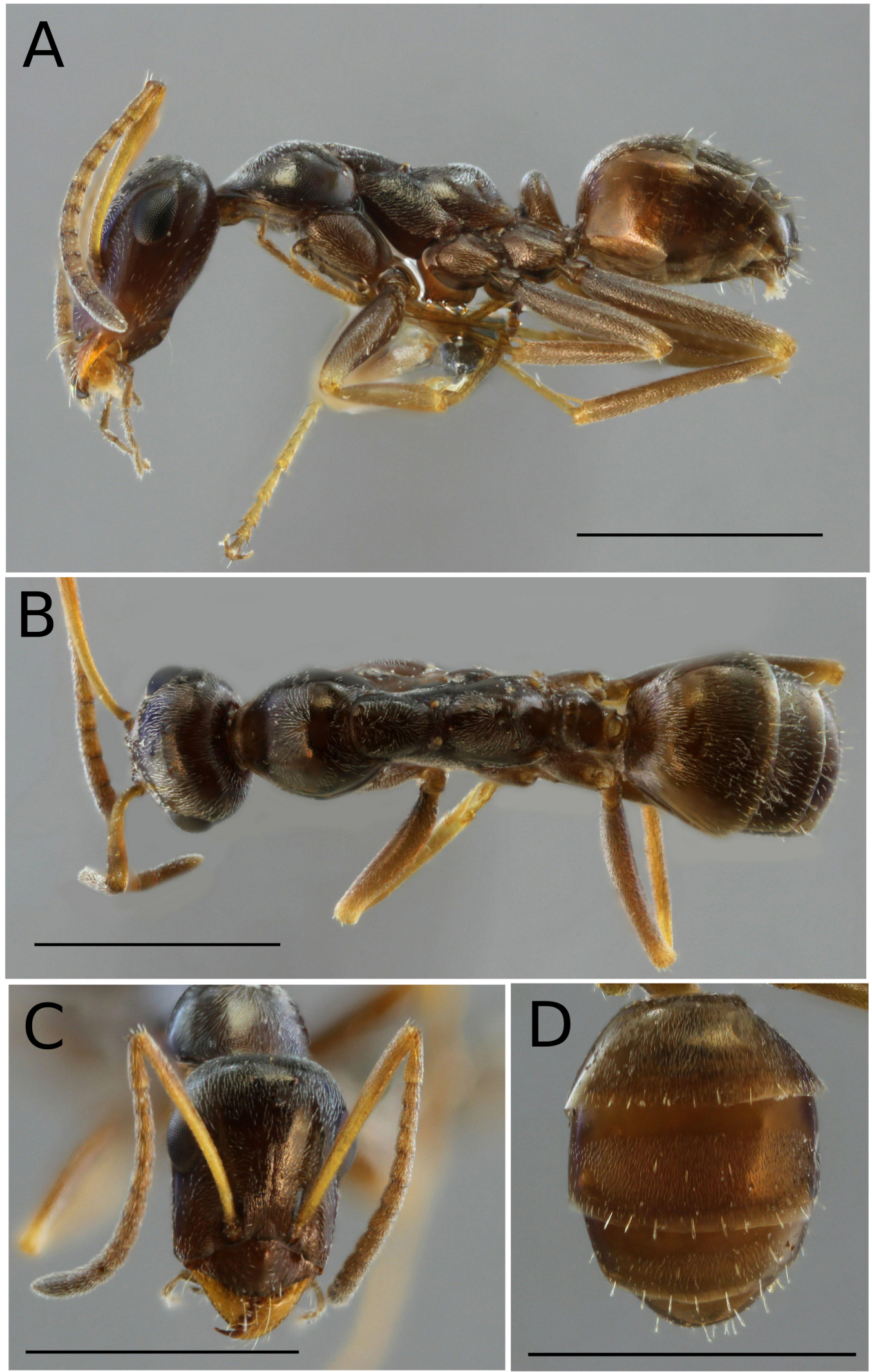

Fig. 6. Proformica nasuta Nylander, 1856, neotype, minor worker from colony Beaucaire 1, France. A. Lateral view. B. Dorsal view. C. Head in full face view. D. Gaster in dorsal view. Scale bars $=1 \mathrm{~mm}$. Automontage: Claude Lebas. 
Media and major workers $(\mathrm{n}=25)$

CW 900-1240 $\mu \mathrm{m}$; nCH 0-1 (0.13); nCU 0-4 (1.13); nTx 0-7 (1.6); nSc 0-4 (0.27); nG 0-7 (2.3); PDG 10-18 (14.2); GHL 35-90 $\mu \mathrm{m}$ (60.2); GHL/CW 0.039-0.091 (0.054).

Body uniformly dark brown to black, appendices and mandibles lighter. Erect hairs rare or absent, short when present $(\mathrm{GHL} / \mathrm{CW}<0.11)$. Dense pubescence on dorsal surface of first and second gaster tergites $(\mathrm{PDG}<29)$. Profile of mesosoma sinuous. Petiolar scale erect, thick, slightly notched at summit in large workers. Head of minor workers clearly elongate, rectangular $(\mathrm{CL} / \mathrm{CW}>1.3)$. Head of media and major workers less elongate (CL/CW 1.1-1.3), a bit shiny toward occiput, faintly sculptured in anterior part. Clypeus finely striate longitudinally. Mandible with five teeth of increasing size from base to apex.

Queen $(\mathrm{n}=8)$

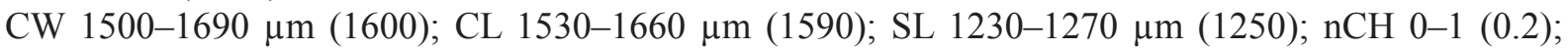

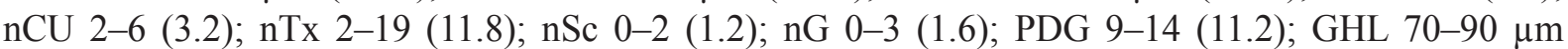
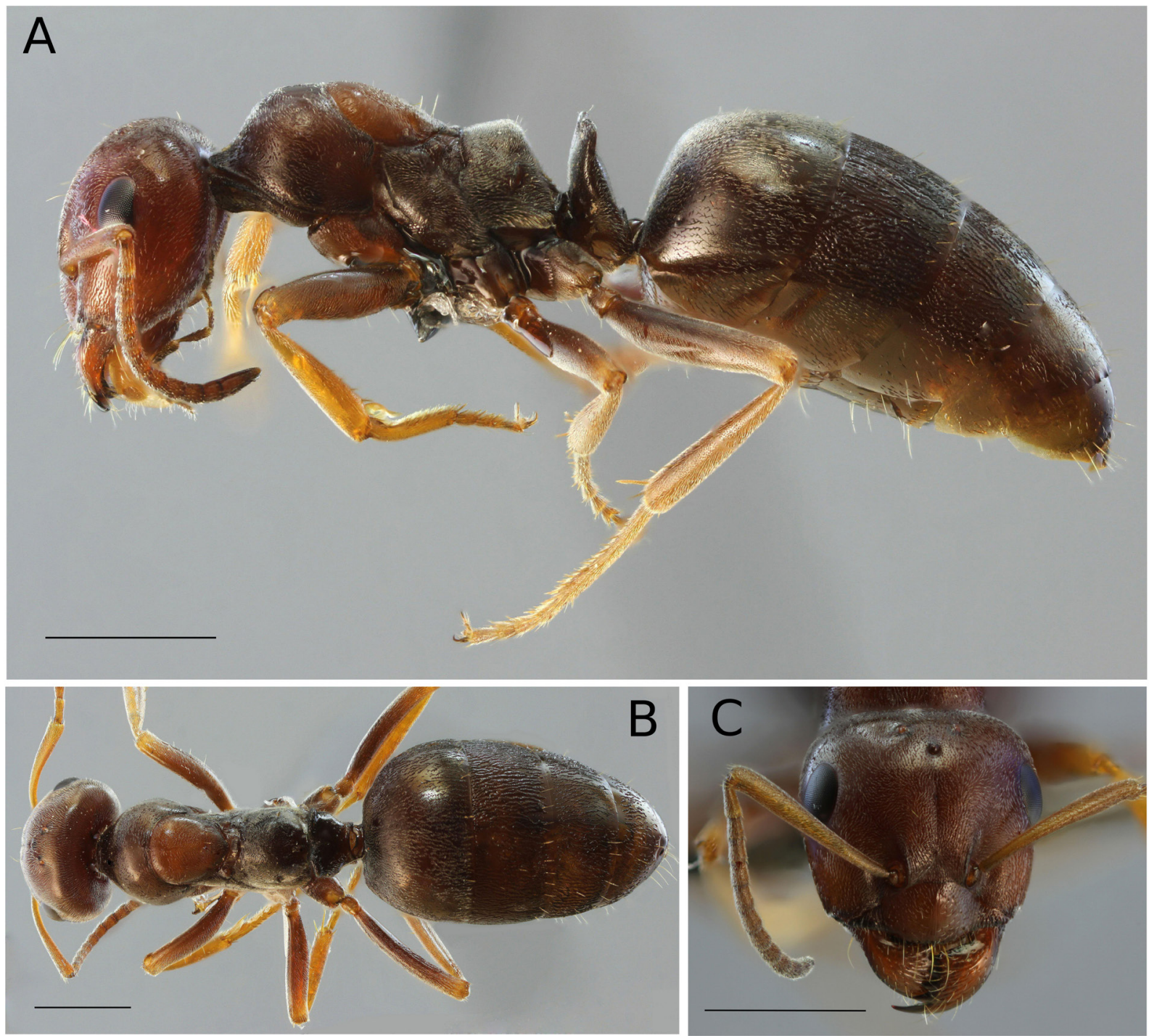

Fig. 7. Proformica nasuta Nylander, 1856, queen from colony Beaucaire 1, France. A. Lateral view. B. Dorsal view. C. Head in full face view. Scale bars $=1 \mathrm{~mm}$. Automontage: Claude Lebas. 
(77.5); MW 1020-1240 $\mu \mathrm{m}$ (1150); ML 2040-2310 $\mu \mathrm{m}$ (2200); ScW 620-860 $\mu \mathrm{m}$ (710); GHL/CW 0.042-0.056 (0.048).

Only ergatoid queens collected. Body brown with a wide orange spot on mesosoma on some specimens. Few and relatively short erect hairs $(\mathrm{nG}<10, \mathrm{GHL}<90 \mu \mathrm{m})$. Pubescence very dense on the dorsal
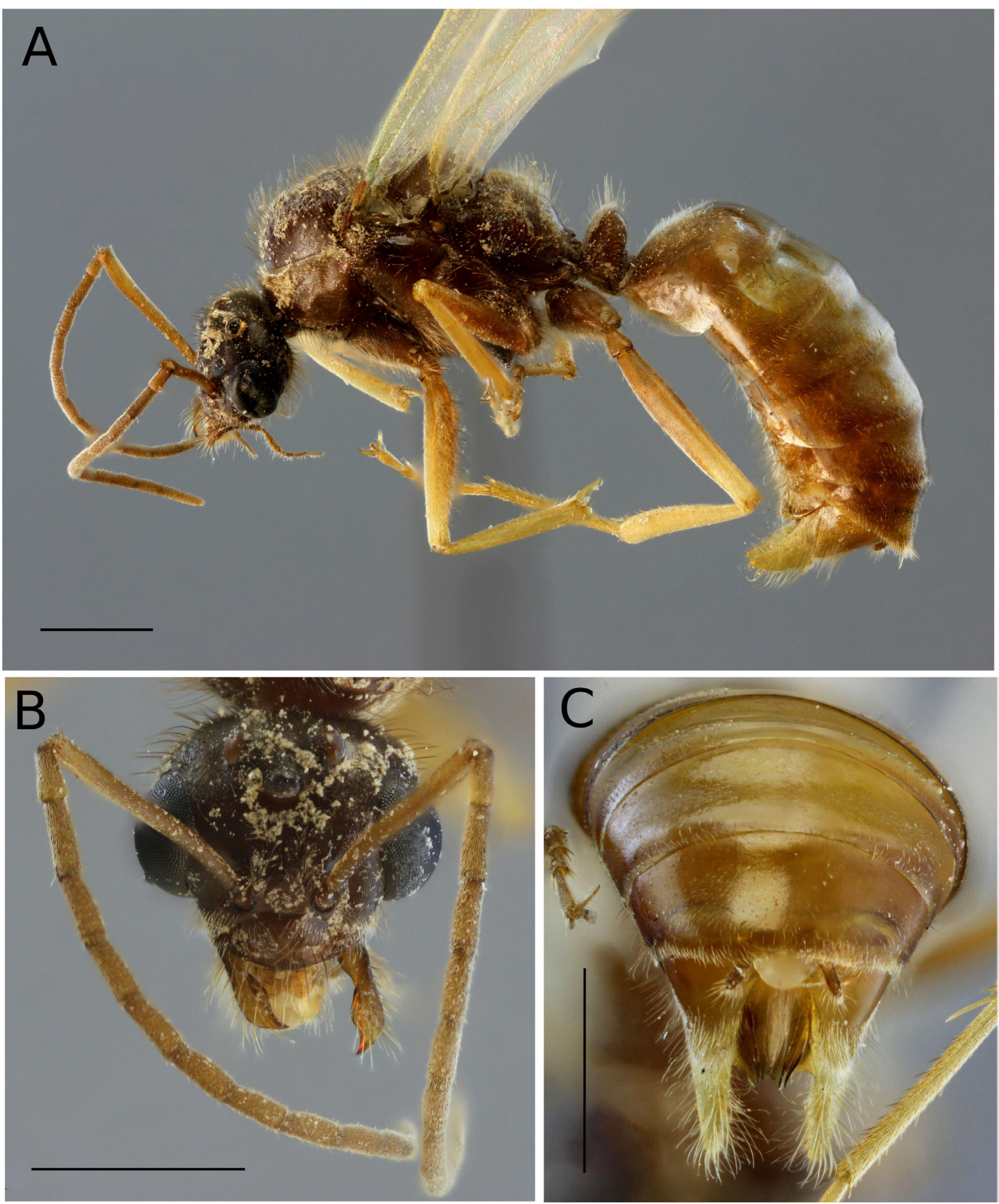

Fig. 8. Proformica nasuta Nylander, 1856, male from colony Tarascon 1, France. A. Lateral view. B. Head in full face view. C. Genitalia in dorsal view. Scale bars $=1 \mathrm{~mm}$. Automontage: Claude Lebas. 
surface of first and second gaster tergites. Profile of mesosoma similar to that of worker, but mesonotum more domed and propodeum very high. Tegulae absent. Petiolar scale high and wide, distinctly notched at summit. Head as long as wide. Same sculpture as in worker.

Male $(\mathrm{n}=6)$

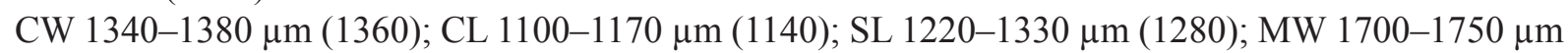
(1730); ML 2720-2970 $\mu \mathrm{m}$ (2830); ScW 560-590 $\mu \mathrm{m}$ (580).

Head, mesosoma and scale dark brown, appendices and sometimes gaster lighter. Erect hairs numerous and dense on entire head, mesosoma and petiolar scale, becoming rare on gaster, where restricted to anterior face of first tergite, angled. Pubescence almost lacking on dorsal surface of gaster tergites. Eyes and ocelli prominent. Mandibles reduced, without teeth. Many erect black hairs on extensor profile of anterior and median femurs. Maximal length of these hairs shorter than width of femur. Rare erect white hairs on tibias. Wings well developed, yellowish.

\section{Distribution}

Southern France (Fig. 1).

\section{Remarks}

We have not examined the type specimens of the Asian varieties of this species, $P$. nasuta metalica Kuznetsov-Ugamsky, 1923 and P. nasuta syrdariana Santschi, 1928, described from Kazakhstan, nor the type specimen of the taxon Formica aerea (Roger, 1859), which was described based on a single minor worker collected in Greece and later synonymized with P. nasuta by Emery (1925). Although we decided not to change the status of these eastern taxa until a thorough revision of the eastern Proformica is undertaken, we believe it is very unlikely that they will be conspecific with $P$. nasuta.

\section{Proformica longipilosa sp. nov. urn:Isid:zoobank.org:act:6EF784CD-C8B2-4474-840E-04AFE460C0CE}

Figs 9-10

\section{Diagnosis}

Workers varying greatly in size, the smallest having a strongly elongated head. Body black. Pubescence sparse and sculpture of tegument weak, giving a shiny aspect. Hairs on mesosoma and gaster very long.

\section{Etymology}

The epithet of this species refers to the long erect hairs on the mesosoma and gaster of workers.

\section{Material examined}

\section{Holotype}

FRANCE: minor worker from colony Mont Ventoux 10 of this study, $44.15261^{\circ} \mathrm{N}, 5.32081^{\circ} \mathrm{E}$, alt. 1442 m, 14 Jul. 2011, coll. R. Blatrix (MNHN 1598).

\section{Paratypes}

FRANCE: Same collection data (including nest) as holotype: 10 workers, (MNHN 1598); other workers in AT (15556), LB, SMNH, XE and collections of the authors; queen (MNHN 1598).

\section{Museum material}

FRANCE: MHNG-FC: 47 specimens, Orange, 14 Sep. 1883. - MCSN-EC: Orange, label with bad handwriting which could be by Forel. - MNHN-BAC: Mont Ventoux, S face, Drôme, 16 Sep. 1978, coll. 
Casevitz-Weulersse; 8 workers ( 2 pins), Gréolières, Alpes-Maritimes; $\sim 30$ workers ( 9 pins), Plateau de Caussols. - MCZL-KC: 5 pins, Caussol, S France, 9 Jun. 1954, leg. Stumper.

\section{New material}

FRANCE: All in personal collections of CG and RB: Plateau de Calern, 22 workers, $43.7553^{\circ} \mathrm{N}, 6.9113^{\circ} \mathrm{E}$, leg. C. Galkowski, Aug. 2012, leg. A. Touchard; Plateau de Caussols, 23 workers, $43.7319^{\circ} \mathrm{N}$, $6.9426^{\circ}$ E, leg. C. Galkowski, Jun. 2012, leg. A. Touchard; Gréolières, 14 workers, $43.82^{\circ}$ N, $6.92^{\circ}$ E, Aug. 2012, leg. A. Touchard; Orange, 13 workers, 2 queens, $44.1344^{\circ} \mathrm{N}, 4.8084^{\circ} \mathrm{E}, 14 \mathrm{Jul} .2011$, leg. R. Blatrix; Sisteron, 12 workers, $44.1989^{\circ}$ N, 5.9419 E, 17 Jun. 2012, leg. R. Blatrix; Mont Ventoux, 41 workers, 4 queens, $44.1519^{\circ}$ N, 5.3226 ${ }^{\circ}$ E, 2009, leg. C. Galkowski, 14 Jul. 2011, leg. R. Blatrix, Aug. 2011, leg. C. Lebas.

\section{Description}

Minor worker $(\mathrm{n}=72)$

CW 540-900 $\mu \mathrm{m}$; nCH 0-10 (4.5); nCU 0-8 (3.4); nTx 3-23 (12.9); nSc 0-7 (3.4); nG 1-27 (10.1); PDG 34-48 (40.3); GHL 70-170 $\mu \mathrm{m}$ (123.7); GHL/CW 0.124-0.263 (0.171).

\section{Media and major worker $(\mathrm{n}=53)$}

CW 900-1530 $\mu \mathrm{m}$; nCH 2-15 (8.4); nCU 2-17 (7.1); nTx 20-75 (38.9); nSc 3-22 (7.6); nG 12-43 (24.8); PDG 24-68 (43.7); GHL 140-240 $\mu \mathrm{m}$ (178.9); GHL/CW 0.117-0.186 (0.145).

Body black; only tibiae, scape and mandible brown. All parts of body with long erect hairs (GHL/CW > 0.12). Pubescence on dorsal surface of first gaster tergite sparse in all worker categories (PDG > 24), revealing smooth and shining cuticle. Profile of mesosoma sinuous. Petiolar scale erect, thick, slightly notched at summit in large workers. Head of minor workers clearly elongate, but less than in P. nasuta (CL/CW 1.16-1.28). Head of media and major workers even less elongate (CL/CW 1.046-1.19). Clypeus finely striate longitudinally, with faint trace of median carina. Frontal triangle and space between frontal carina also finely striate. Sculpture disappears toward occiput, cuticle becoming smooth and shining, or faintly punctuated in large workers. Scape long, surpassing occipital border.

\section{Queen $(\mathrm{n}=6)$}

CW 1530-1770 $\mu \mathrm{m}$ (1690); CL 1550-1750 $\mu \mathrm{m}$ (1660); SL 1220-1390 $\mu \mathrm{m}$ (1300); nCH 4-13 (8.20); nCU 5-7 (6.20); nTX 62-92 (79); nSc 8-13 (11.2); nG 26-36 (31.5); PDG 12-17 (14.5);

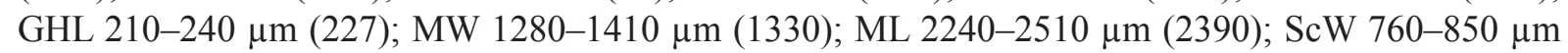
(820); GHL/CW 0.124-0.141 (0.135).

Color as in worker. Many long and erect hairs on all body parts ( $\mathrm{nG}>26$, GHL $>200 \mu \mathrm{m})$. Some erect hairs also on femora and tibiae. Dense pubescence on entire body, masking surface of cuticle. Mesosoma less wide than head. Wing remains indicate winged queens, although wings possibly small given reduced development of scutum and scutellum. Petiolar scale high and wide, deeply notched at summit. Gaster rather small. Head almost as large as long, entirely and finely sculptured, faint riddles of anterior part replaced by puncture on posterior part, giving head an almost dull aspect. Clypeus finely striate longitudinally. Scape surpassing occipital border.

\section{Male}

Unknown.

\section{Distribution}

Southern France (Fig. 1). 

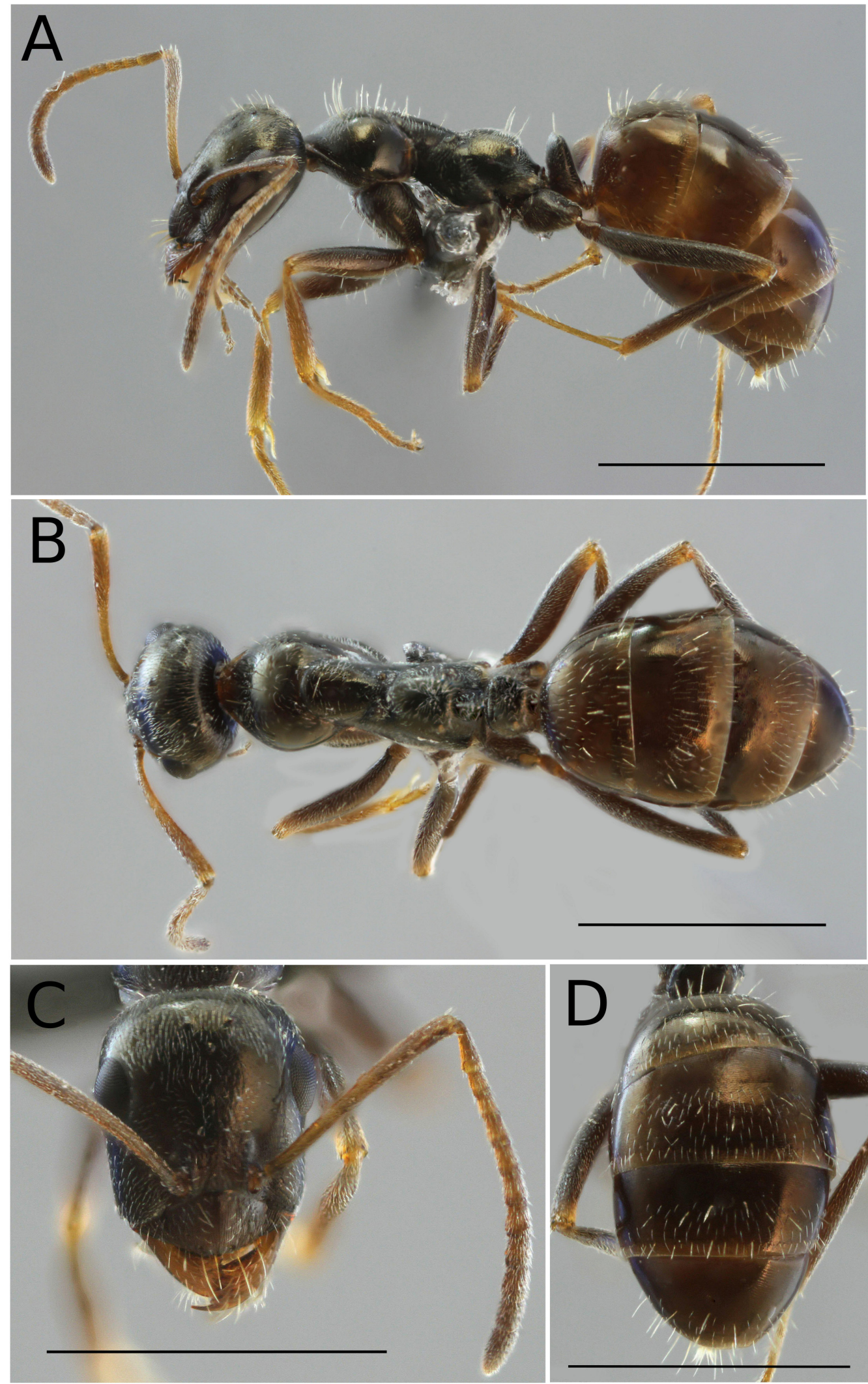

Fig. 9. Proformica longipilosa sp. nov., holotype, minor worker from colony Mont Ventoux 10, France. A. Lateral view. B. Dorsal view. C. Head in full face view. D. Gaster in dorsal view. Scale bars $=1 \mathrm{~mm}$. Automontage: Claude Lebas. 


\section{Remarks}

We made direct comparisons between specimens of $P$. longipilosa sp. nov. and $P$. longiseta (A. Tinaut leg.) from Sierra Nevada, Spain, and P. ferreri (IRSNB-BC, 2 workers, 1 o (type specimen) from Spain). The latter two species, in addition to $P$. nasuta, were formally described from western Europe. Specimens of $P$. longipilosa sp. nov. are unambiguously distinguished from those of these two species by the combination of the following characters: erect hairs on the body are longer (GHL/CW $>0.12$ ) and the pubescence on the dorsal surface of the first gaster tergite is sparser. This last character is especially discriminant in media and major workers (PDG 24-68, mean =43.7). In addition, the cuticle is smoother, giving a shinier appearance, in particular on the head.

\section{Discussion}

Based on arguments from morphometric analysis, DNA sequences and cuticular hydrocarbons, we show that the populations of Proformica in southern France belong to two species, one of which is P. nasuta, and the other a new species that we name P. longipilosa sp. nov.

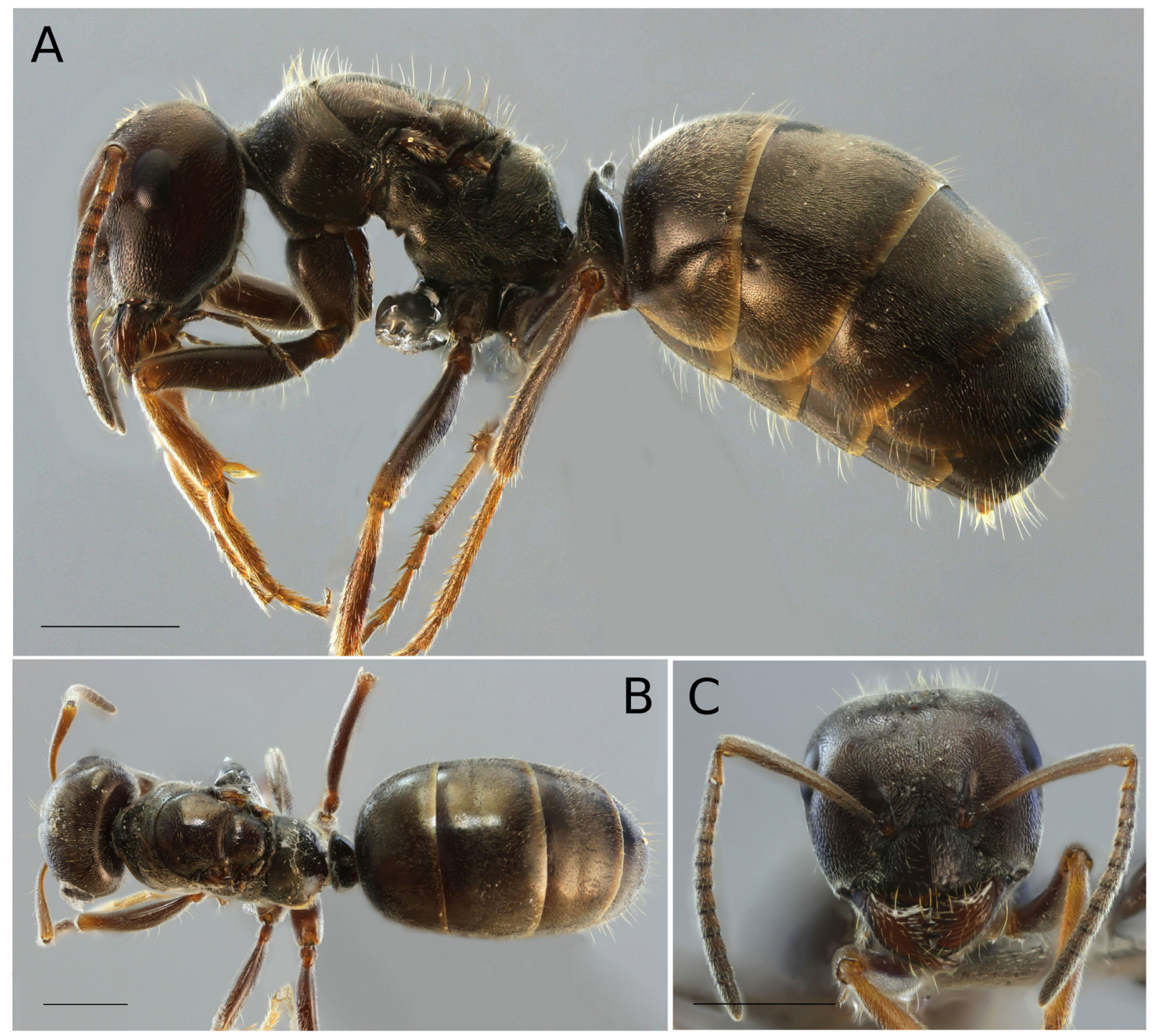

Fig. 10. Proformica longipilosa sp. nov., queen from colony Mont Ventoux 10, France. A. Lateral view. B. Dorsal view. C. Head in full face view. Scale bars $=1 \mathrm{~mm}$. Automontage: Claude Lebas. 


\section{Consequences for the taxonomy of Proformica}

There has been much confusion in the concept of the taxon P. nasuta, in part because the type appears to have been lost a long time ago. None of the taxonomic studies published after the description of the species by Nylander (1856) made reference to the type, which was collected in Beaucaire (France). Forel (1886) described the worker and the queen from specimens collected in Orange (France) and sent samples to many of his colleagues throughout Europe and Russia. We examined the specimens from Orange in the Forel, Emery and Bondroit collections, and we collected new samples from the same locality in 2011. All differ markedly from those of Beaucaire and belong to the new species we describe in this study, P. longipilosa sp. nov. All the taxonomic studies after 1886 used the samples from Orange, or descriptions of them, as a reference for $P$. nasuta. These studies described P. nasuta as having long erect hairs and sparse pubescence (e.g., Ruzsky 1905; Emery 1909; Wheeler 1913; Bondroit 1918; Santschi 1925; Bernard 1968; Dlussky 1969; Collingwood 1976; Agosti \& Collingwood 1987), two characters that are typical of $P$. longipilosa sp. nov. Other specimens from southeastern France (Plateau de Caussols, Tourettes-sur-Loup) have also been used as references for P. nasuta (Collingwood 1956; Stumper 1957; Dlussky 1969), but they come from an area that we now recognise as belonging to the range of $P$. longipilosa sp. nov., and are thus likely distinct from $P$. nasuta. This mistake has been perpetuated so that the actual conception of $P$. nasuta refers to $P$. longipilosa sp. nov. A consequence of this is that all reports of $P$. nasuta since 1886, including all those from eastern Europe and Asia, are probably erroneous.

There is a striking similarity between the biogeographic patterns of the genus Proformica and those observed for other steppe elements (Ruano et al. 2011; Sanllorente et al. 2015) such as, for instance, the meadow and steppe vipers (Vipera ursinii species complex). Both Proformica and the V. ursinii complex are known to occupy the same type of habitats and show the same pattern of disjunct distribution, with one area across Asia and one area restricted to western Europe. Moreover, they are both poor dispersers (Sanllorente et al. 2015; Ferchaud et al. 2011). It is likely that the current distribution and speciation patterns of the two groups have been induced by the same climatic and geographic events. The eastern and western clades of the Vipera ursinii species complex diverged about 4 Mya (Zinenko et al. 2015), and the taxa from the two geographic areas are completely distinct. In addition, mutation rates and the number of generations per unit time are expected to be higher in insects than in snakes (Martin \& Palumbi 1993). We thus expect that the Proformica species from western Europe are distinct from those from the East.

\section{Intraspecific variation}

Localities for P. nasuta can be divided into two subgroups. One is composed of lowland localities that can be close to each other and form an almost continuous distribution in the plain of the Languedoc and the Rhône valley (Montpellier, Sauteyrargues, Pompignan, Grospierres, Collias, Beaucaire, Jonquières, Tarascon, Plaine de la Crau, Aurons and Bonnieux). The other subgroup is composed of localities isolated on the summits of medium-sized mountains (Sumène, Sainte-Baume, Grand Luberon and Montagne de Lure). Beyond ecological differences (mountain vs lowland), the distinction between the two groups is supported by the analysis of morphological characters, DNA and cuticular hydrocarbons. Except for Sumène, individuals from mountain localities have some erect hairs on the mesosoma, whereas hairs are lacking in most lowland individuals. Mountain individuals also have longer hairs and sparser pubescence on the gaster compared to lowland individuals. Interestingly, mitochondrial sequences from Sainte-Baume, Grand Luberon and Montagne de Lure form three monophyletic clades that are highly differentiated from each other, whereas most of the lowland localities show little differentiation. This pattern is consistent with a particularly high degree of isolation of the mountain localities, as already shown for P. longiseta in Spain (Sanllorente et al. 2015). Cuticular hydrocarbons also differ between lowland and mountain localities. At this stage we are reluctant to consider the mountain localities as 
a separate species because lowland and mountain localities form a consistent group morphologically and do not form two monophyletic clades in the mitochondrial phylogenies. Instead, we consider that the population of each mountain locality is derived independently from the lowland population. Sanllorente et al. (2015) proposed that climate-driven range fluctuation of populations of $P$. longiseta during Pleistocene glaciations induced a strong isolation among populations that are now restricted to mountain tops in southern Spain, because this species is adapted to cold and arid environments. Extant populations would be derived from an ancient, large population, independently from each other. A similar process may explain the divergence we noted between lowland and mountain populations of $P$. nasuta, and among mountain populations, and may have induced local adaptation of mountain populations. The morphological features of the mountain individuals of $P$. nasuta make them more similar to P. longipilosa sp. nov., especially where localities of the two species are close to each other (Grand Luberon and Montagne de Lure). These features might be the result either of introgression of $P$. longipilosa sp. nov. into populations of $P$. nasuta, or of morphological convergence in response to a similar environment.

Proformica longipilosa sp. nov. also shows two subgroups. One is composed of populations from localities on plateaus and mountains (Plateau de Calern, Plateau de Caussols, Gréolières and Mont Ventoux) and the other is composed of lower elevation localities (Orange, Sisteron and Vinsobre). Individuals of the lowland localities tend to have shorter hairs and denser pubescence on the gaster than those from highelevation localities, and thus are morphologically closer to $P$. nasuta than the high-elevation individuals. As proposed for $P$. nasuta, these features could result from either introgression or convergence. Although lowland $P$. longipilosa sp. nov. and mountain P. nasuta tend to converge morphologically, they can still be easily distinguished, leaving no doubt regarding their assignment to species. All nests from the three low-elevation localities of $P$. longipilosa sp. nov. had mitochondrial sequences typical of $P$. nasuta. We hypothesise that this incongruence between morphological and molecular characters, specifically for low-elevation localities, results from introgression of mitochondrial DNA from P. nasuta to $P$. longipilosa sp. nov. Such introgression would be most likely to occur in low-elevation localities because $P$. nasuta is relatively widespread in the lowlands. Complete or gene-specific introgression of maternal DNA is a well-known phenomenon in insects (Ballard 2000; Chan \& Levin 2005; Linnen \& Farrell 2007). An isolated event of partial mitochondrial introgression is also suggested in Plateau de Calern, where all nests were morphologically classified as $P$. longipilosa sp. nov., but one had Cytb sequences typical of $P$. nasuta. All other nests in this locality fitted within $P$. longipilosa sp. nov. for both mitochondrial markers. It is worth noting that we could not find any locality with nests of both $P$. nasuta and $P$. longipilosa sp. nov., although the two can be found in similar habitats.

\section{Interpretation of cuticular hydrocarbons}

Cuticular hydrocarbons separate the two species without ambiguity. Populations from all localities of P. nasuta form a homogeneous clade with relatively little differentiation except for two localities isolated at the summits of mountains (Grand Luberon and Montagne de Lure). Proformica longipilosa sp. nov. (Mont Ventoux and Sisteron) appears to be well separated from all other ants studied here, including the outgroups (P. longiseta and Cataglyphis Förster, 1850), confirming its status as a separate species. This classification is globally consistent with spatial distribution of the localities and with the classification based on morphology and DNA sequences. Localities of P. nasuta from the lowlands form continuous populations without important geographical isolation, allowing regular exchange of migrants resulting in little differentiation of cuticular hydrocarbons. However, the mountain localities Grand Luberon and Montagne de Lure are isolated and, probably as a consequence, are divergent for cuticular hydrocarbons. On the mitochondrial tree they also diverge from other localities of $P$. nasuta. Cuticular hydrocarbons in Proformica appear to be linked to phylogenetic signature but seem to change rapidly with geographical isolation, even faster than mitochondrial DNA. Geographic variation in cuticular hydrocarbons depends on the taxon. For instance, profiles are very stable for Formica ants from Finland to Great Britain (Martin 
et al. 2008) and for Lasius niger Linnaeus, 1758 from Denmark to the south of France (Lenoir et al. 2009; Lenoir unpubl.). In contrast, rapid spatial changes in hydrocarbons are present in some taxa like Odontomachus Latreille, 1804 (Smith et al. 2013) and Cataglyphis (Dahbi et al. 1996). Interestingly, Rossomyrmex minuchae Tinaut, 1981, a slave-maker parasite of Proformica longiseta, also has different chemotypes in three populations in Sierra Nevada, Spain (Sanllorente et al. 2012). It is noteworthy that the genus Cataglyphis is phylogenetically, biologically and ecologically very close to Proformica. Both have very limited queen dispersal, are specialized on dry habitats and forage on dead invertebrates at the warmest time of the day. It would be worth investigating whether strong divergence in cuticular hydrocarbons within species could be related to one or more of these characteristics.

\section{Conclusions}

Although we relied on an integrative taxonomy approach, using several complementary sources of information, we confirm the general view that the taxonomy of the genus Proformica is a complex problem. The nuclear markers chosen for use here evolve too slowly and thus lack resolution. Information from mitochondrial genes is blurred by genetic processes such as transposition and introgression and may be biased by queen philopatry. Our results suggest that morphology is a better tool to resolve taxonomy in this genus than either cuticular hydrocarbons or DNA sequences of the genes commonly used for phylogenetic analyses and barcoding, although genetic markers other than those used in this study should also be investigated. However, for the genus Proformica, the zoogeographical region of southern France is the least complex in taxonomic terms. Thus, the morphological approach developed in this paper may prove unreliable in other regions, such as the Iberian Peninsula and eastern Europe. A population-genetic approach using tools such as microsatellites or single nucleotide polymorphisms from Next Generation Sequencing (e.g., RADseq) may help disentangle this taxonomic knot.

\section{Acknowledgements}

This project was supported by the network "Bibliothèque du Vivant" funded by CNRS, MNHN, INRA and the CEA (Centre National de Séquençage). We thank Axel Touchard, Théotime Colin, Philippe Geniez and V. Bouchet for providing ant samples, Nicolas Lescureux for help with translation of papers in Russian, Hugo Darras, Marek Borowiec, Birgit Schlick-Steiner and Omid Paknia for useful comments on an earlier version of the manuscript, Alberto Tinaut and Xavier Espadaler for constructive remarks, Alberto Tinaut for sending specimens of $P$. longiseta from Sierra Nevada, Doyle McKey and Finn Kjellberg for English editing, Agnièle Touret-Alby and Quentin Rome (MNHN) for data on the specimens of Proformica in the Paris collections and for the loan of specimens, and Bernhard Merz (Entomology Department, MHNG), Wouter Dekoninck (Entomology Department, IRSNB), Isabelle Zürcher-Pfander (NMB), Roberto Poggi (MCSN) and Anne Freitag (MCZL) for communicating data regarding the collections of A. Forel, J. Bondroit, F. Santschi, C. Emery and H. Kutter, respectively.

\section{References}

Agosti D. 1994. The phylogeny of the ant tribe Formicini (Hymenoptera, Formicidae) with the description of a new genus. Systematic Entomology 19: 93-117. https://doi.org/10.1111/j.1365-3113.1994.tb00581.x

Agosti D. \& Collingwood C.A. 1987. A provisional list of the Balkan ants (Hym. Formicidae) with a key to the worker caste. II. Key to the worker caste, including the European species without the Iberian. Mitteilungen der Schweizerischen Entomologischen Gesellschaft 60: 261-293.

Ballard J.W.O. 2000. When one is not enough: Introgression of mitochondrial DNA in Drosophila. Molecular Biology and Evolution 17: 1126-1130. https://doi.org/10.1093/oxfordjournals.molbev. $\underline{\mathrm{a} 026394}$ 
Belshaw R. \& Quicke D.L.J. 1997. Amolecular phylogeny of the Aphidiinae (Hymenoptera: Braconidae). Molecular Phylogenetics and Evolution 7: 281-293. https://doi.org/10.1006/mpev.1996.0400

Bernard F. 1968. Faune de l'Europe et du Bassin Méditerranéen. 3. Les Fourmis (Hymenoptera Formicidae) d'Europe occidentale et septentrionale. Masson, Paris.

Bolton B. 2014. An Online Catalog of the Ants of the World. Available from http://antcat.org [accessed 26 Jan. 2017].

Bondroit J. 1918. Les fourmis de France et de Belgique. Annales de la Société Entomologique de France 87: 1-174.

Chan K.M.A. \& Levin S.A. 2005. Leaky prezygotic isolation and porous genomes: Rapid introgression of maternally inherited DNA. Evolution 59: 720-729. https://doi.org/10.1554/04-534

Collingwood C.A. 1956. Ant hunting in France. L'entomologiste 89: 105-108.

Collingwood C.A. 1976. A provisional list of Iberian Formicidae with a key to the worker caste. EOS Revista Española de Entomologia 52: 65-95.

Collingwood C.A. \& Yarrow I.H.H. 1969. A survey of Iberian Formicidae. EOS - Revista Espanola de Entomologia 44: 53-101.

Dahbi A., Cerda X., Hefetz A. \& Lenoir A. 1996. Social closure, aggressive behavior, and cuticular hydrocarbon profiles in the polydomous ant Cataglyphis iberica (Hymenoptera, Formicidae). Journal of Chemical Ecology 22: 2173-2186. https://doi.org/10.1007/BF02029538

Dlussky G.M. 1969. Ants of the genus Proformica Ruzs. of the USSR and contiguous countries (Hymenoptera: Formicidae). Zoologicheskii Zhurnal 48: 217-232. [in Russian]

Edgar R.C. 2004. MUSCLE: multiple sequence alignment with high accuracy and high throughput. Nucleic Acids Research 32: 1792-1797. https://doi.org/10.1093/nar/gkh340

Emery C. 1909. Beiträge zur Monographie der Formiciden des paläarktischen Faunengebietes (Hym.). Teil VII. Deutsche Entomologische Zeitschrift 1909: 179-204.

Emery C. 1925. Hymenoptera, Fam. Formicidae, subfam. Formicinae. Genera Insectorum 183: 1-302.

Errard C., Ruano F., Richard F.J., Lenoir A., Tinaut A. \& Hefetz A. 2006. Co-evolution-driven cuticular hydrocarbon variation between the slave-making ant Rossomyrmex minuchae and its host Proformica longiseta (Hymenoptera: Formicidae). Chemoecology 16: 235-240. https://doi.org/10.1007/s00049$\underline{006-0358-4}$

Espadaler X. \& Cagniant H. 1987. Contribution à la connaissance des fourmis marocaines. Description du mâle de Proformica theryi Santschi, 1936 (Hymenoptera, Formicidae). Nouvelle Revue d'Entomologie 4: 133-138.

Ferchaud A.L., Lyet A., Cheylan M., Arnal V., Baron J.P., Montgelard C. \& Ursenbacher S. 2011. High genetic differentiation among French populations of the Orsini's Viper (Vipera ursinii ursinii) based on mitochondrial and microsatellite data: implications for conservation management. Journal of Heredity 102: 67-78. https://doi.org/10.1093/jhered/esq098

Forel A. 1886. Études myrmécologiques en 1886. Annales de la Société Entomologique de Belgique 30: $131-215$.

Goropashnaya A.V., Fedorov V.B., Seifert B. \& Pamilo P. 2004. Limited phylogeographical structure across Eurasia in two red wood ant species Formica pratensis and F. lugubris (Hymenoptera, Formicidae). Molecular Ecology 13: 1849-1858. https://doi.org/10.1111/j.1365-294X.2004.02189.X 
Goropashnaya A.V., Fedorov V.B., Seifert B. \& Pamilo P. 2007. Phylogeography and population structure in the ant Formica exsecta (Hymenoptera, Formicidae) across Eurasia as reflected by mitochondrial DNA variation and microsatellites. Annales Zoologici Fennici 44: 462-474.

Goropashnaya A.V., Fedorov V.B., Seifert B. \& Pamilo P. 2012. Phylogenetic relationships of Palaearctic Formica species (Hymenoptera, Formicidae) based on mitochondrial cytochrome $b$ sequences. PLoS ONE 7: e41697. https://doi.org/10.1371/journal.pone.0041697

Hasegawa E., Tinaut A. \& Ruano F. 2002. Molecular phylogeny of two slave-making ants: Rossomyrmex and Polyergus (Hymenoptera: Formicidae). Annales Zoologici Fennici 39: 267-271.

Hebert P.D.N., Penton E.H., Burns J.M., Janzen D.H. \& Hallwachs W. 2004. Ten species in one: DNA barcoding reveals cryptic species in the neotropical skipper butterfly Astraptes fulgerator. Proceedings of the National Academy of Sciences 101: 14812-14817. https://doi.org/10.1073/pnas.0406166101

Lanfear R., Calcott B., Ho S.Y.W. \& Guindon S. 2012. PartitionFinder: combined selection of partitioning schemes and substitution models for phylogenetic analyses. Molecular Biology and Evolution 29: 16951701. https://doi.org/10.1093/molbev/mss020

Lenoir A., Depickere S., Devers S., Christides J.P. \& Detrain C. 2009. Hydrocarbons in the ant Lasius niger: from the cuticle to the nest and home range marking. Journal of Chemical Ecology 35: 913-921. https://doi.org/10.1007/s10886-009-9669-6

Liautard C. \& Keller L. 2001. Restricted effective queen dispersal at a microgeographic scale in polygynous populations of the ant Formica exsecta. Evolution 55: 2484-2492. https://doi. org/10.1111/j.0014-3820.2001.tb00763.x

Linnen C.R. \& Farrell B.D. 2007. Mitonuclear discordance is caused by rampant mitochondrial introgression in Neodiprion (Hymenoptera: Diprionidae) sawflies. Evolution 61: 1417-1438. https:// doi.org/10.1111/j.1558-5646.2007.00114.x

Martin A.P. \& Palumbi S.R. 1993. Body size, metabolic rate, generation time, and the molecular clock. Proceedings of the National Academy of Sciences 90: 4087-4091. https://doi.org/10.1073/pnas.90.9.4087

Martin S.J., Helanterä H. \& Drijfhout F.P. 2008. Evolution of species-specific cuticular hydrocarbon patterns in Formica ants. Biological Journal of the Linnean Society 95: 131-140. https://doi.org/10.1111/ j.1095-8312.2008.01038.x

Moreau C.S., Bell C.D., Vila R., Archibald S.B. \& Pierce N.E. 2006. Phylogeny of the ants: diversification in the age of angiosperms. Science 312: 101-104. https://doi.org/10.1126/science.1124891

Nowbahari E., Lenoir A., Clément J.L., Lange C., Bagnères A.G. \& Joulie C. 1990. Individual, geographical and experimental variation of cuticular hydrocarbons of the ant Cataglyphis cursor (Hymenoptera: Formicidae): their use in nest and subspecies recognition. Biochemical Systematics and Ecology 18: 63-73. https://doi.org/10.1016/0305-1978(90)90036-F

Nylander W. 1856. Synopsis des formicides de France et d'Algérie. Annales des Sciences Naturelles: Zoologie et Biologie Animale, $4^{\text {th }}$ Series 5: 51-109. Available from http://biodiversitylibrary.org/ page/13469211 [accessed 12 Feb. 2017].

Oppelt A., Spitzenpfeil N., Kroiss J. \& Heinze J. 2008. The significance of intercolonial variation of cuticular hydrocarbons for inbreeding avoidance in ant sexuals. Animal Behaviour 76: 1029-1034. https://doi.org/10.1016/j.anbehav.2008.05.020

Radchenko A. 2007. The ants (Hymenoptera, Formicidae) in the collection of William Nylander. Fragmenta Faunistica (Warsaw) 50: 27-41.

Reyment R.A. 1989. Compositional data analysis. Terra Review 1: 29-34. 
Ronquist F., Teslenko M., van der Mark P., Ayres D.L., Darling A., Hohna S., Larget B., Liu L., Suchard M.A. \& Huelsenbeck J.P. 2012. MrBayes 3.2: efficient Bayesian phylogenetic inference and model choice across a large model space. Systematic Biology 61: 539-542. https://doi.org/10.1093/ sysbio/sys029

Ruano F., Devers S., Sanllorente O., Errard C., Tinaut A. \& Lenoir A. 2011. A geographical mosaic of coevolution in a slave-making host-parasite system. Journal of Evolutionary Biology 24: 1071-1079. https://doi.org/10.1111/j.1420-9101.2011.02238.x

Ruzsky M. 1905. The ants of Russia. Trudy Obshchestva Estestvoispytatelei pri Imperatorskom Kazanskom Universitete 38: 1-800. [in Russian]

Sanllorente O., Lorite P., Devers S., Ruano F., Lenoir A. \& Tinaut A. 2012. The spatial distribution does not affect host-parasite coevolution in Rossomyrmex ants. Insectes Sociaux 59: 361-368. https://doi. org/10.1007/s00040-012-0228-8

Sanllorente O., Ruano F. \& Tinaut A. 2015. Large-scale population genetics of the mountain ant Proformica longiseta (Hymenoptera: Formicidae). Population Ecology 57: 637-648. https://doi. org/10.1007/s10144-015-0505-2

Santschi F. 1925. Fourmis d'Espagne et autres espèces paléarctiques (Hymenopt.). EOS - Revista Española de Entomologia 1: 339-360.

Saux C., Fisher B.L. \& Spicer G.S. 2004. Dracula ant phylogeny as inferred by nuclear 28S rDNA sequences and implications for ant systematics (Hymenoptera: Formicidae: Amblyoponinae). Molecular Phylogenetics and Evolution 33: 457-468. https://doi.org/10.1016/j.ympev.2004.06.017

Schlick-Steiner B.C., Steiner F.M., Seifert B., Stauffer C., Christian E. \& Crozier R.H. 2010. Integrative taxonomy: a multisource approach to exploring biodiversity. Annual Review of Entomology 55: 421438. https://doi.org/10.1146/annurev-ento-112408-085432

Seifert B. 2007. Die Ameisen Mittel- und Nordeuropas. Lutra, Görlitz, Germany.

Smith A.A., Millar J.G., Hanks L.M. \& Suarez A.V. 2013. A conserved fertility signal despite population variation in the cuticular chemical profile of the trap-jaw ant Odontomachus brunneus. Journal of Experimental Biology 216: 3917-3924. https://doi.org/10.1242/jeb.089482

Stamatakis A., Hoover P. \& Rougemont J. 2008. A rapid bootstrap algorithm for the RAxML web servers. Systematic Biology 57: 758-771. https://doi.org/10.1080/10635150802429642

Stumper R. 1957. Sur l'éthologie de la fourmi a miel Proformica nasuta Nyl. (Étude myrmécologique LXXVIII). Bulletin de la Société des Naturalistes Luxembourgeois 60: 87-97.

Tamura K., Peterson D., Peterson N., Stecher G., Nei M. \& Kumar S. 2011. MEGA5: Molecular Evolutionary Genetics Analysis using maximum likelihood, evolutionary distance, and maximum parsimony methods. Molecular Biology and Evolution 28: 2731-2739. https://doi.org/10.1093/molbev/ $\underline{\operatorname{msr} 121}$

Ward P.S. \& Downie D.A. 2005. The ant subfamily Pseudomyrmecinae (Hymenoptera: Formicidae): phylogeny and evolution of big-eyed arboreal ants. Systematic Entomology 30: 310-335. https://doi. org/10.1111/j.1365-3113.2004.00281.x

Wheeler W.M. 1913. A revision of the ants of the genus Formica (Linné) Mayr. Bulletin of the Museum of Comparative Zoology 53: 379-565.

Zinenko O., Stümpel N., Mazanaeva L., Bakiev A., Shiryaev K., Pavlov A., Kotenko T., Kukushkin O., Chikin Y., Duisebajeva T., Nilson G., Orlov N.L., Tuniyev S., Ananjeva N.B., Murphy R.W. \& Joger U. 2015. Mitochondrial phylogeny shows multiple independent ecological transitions and northern 
dispersion despite of Pleistocene glaciations in meadow and steppe vipers (Vipera ursinii and Vipera renardi). Molecular Phylogenetics and Evolution 84: 85-100. https://doi.org/10.1016/j. ympev.2014.12.005

Manuscript received: 1 March 2016

Manuscript accepted: 31 January 2017

Published on: 2 March 2017

Guest editors: Line Le Gall, Frédéric Delsuc, Stéphane Hourdez, Guillaume Lecointre

and Jean-Yves Rasplus

Desk editor: Danny Eibye-Jacobsen

Printed versions of all papers are also deposited in the libraries of the institutes that are members of the EJT consortium: Muséum national d'Histoire naturelle, Paris, France; Botanic Garden Meise, Belgium; Royal Museum for Central Africa, Tervuren, Belgium; Natural History Museum, London, United Kingdom; Royal Belgian Institute of Natural Sciences, Brussels, Belgium; Natural History Museum of Denmark, Copenhagen, Denmark; Naturalis Biodiversity Center, Leiden, the Netherlands. 


\section{Appendices}

Appendix 1. List of the nest samples collected for this study, with geographic locality, number of individuals per nest used for morphological analyses and GenBank accession numbers for DNA markers.

colony\# species locality municipality country date latitude longitude altitude_m collector morpho_workers morpho_queens COI Cytb 28S LwRh

RB0000530 Cataglyphis cursor Riboux (83) France 3Jun.2011 43.32693 5.76608 Rumsais Blatrix KU749638 KU749738

RB0000577 Formica cunicularia Estoher (66) France 25Jun.2011 42.574 2.48461 Rumsais Blatrix KU749784 KU749819

RB0000971 Cataglyphis mauritanica Morocco 27May2012 33.3818 -5.1324 Philippe Geniez KU749639 KU749785 KU749820

RB0001590 Bajcaridris theryi Morocco Jul.2012 Christophe Galkowski KU749786 KU749821

Salon 1 Cataglyphis cursor Salon-de-Provence (13) France Jul.2012 43.63705 5.02083 Claude Lebas KU749640 KU749787 KU749822

Aurons 1 Proformica nasuta Aurons Aurons (13) France May2006 43.66 5.15 199 V. Bouchet 4

Beaucaire 1 Proformica nasuta Beaucaire Beaucaire (30) France 9Jul.2011 43.83544 4.61828 21 Rumsais Blatrix, Claude Lebas 42 KU749600 KU749655

Beaucaire 2 Proformica nasuta Beaucaire Beaucaire (30) France 9Jul.2011 43.83547 4.61858 19 Rumsais Blatrix, Claude Lebas 3 KU749656

Beaucaire 3 Proformica nasuta Beaucaire Beaucaire (30) France 9Jul.2011 43.83533 4.61878 17 Rumsais Blatrix, Claude Lebas 3 KU749601, KU749602 KU749657

Beaucaire 4 Proformica nasuta Beaucaire Beaucaire (30) France 9Jul.2011 43.835314.61928 15 Rumsais Blatrix, Claude Lebas 4 KU749603, KU749604, KU749605 KU749658

Bonnieux 1 Proformica nasuta Bonnieux Bonnieux (84) France 1Oct.2011 43.8625 5.30694 166 Claude Lebas 4 KU749606 KU749659 KU749759 KU749794

Bonnieux 2 Proformica nasuta Bonnieux Bonnieux (84) France 1Oct.2011 43.8625 5.30694 166 Claude Lebas 4 KU749660

Plateau de Calern 10 Proformica longipilosa sp. nov. Plateau de Calern Caussols (06) France 19Aug.2010 43.7514 6.92349 1264 Christophe Galkowski 4

Plateau de Calern 18 Proformica longipilosa sp. nov. Plateau de Calern Caussols (06) France 19Aug.2010 43.7514 6.92349 1264 Christophe Galkowski 4

Plateau de Calern 2 Proformica longipilosa sp. nov. Plateau de Calern Caussols (06) France Aug.2012 43.75325 6.9159 1256 Axel Touchard 3 KU749607 KU749661 KU749760 KU749795

Plateau de Calern 3 Proformica longipilosa sp. nov. Plateau de Calern Caussols (06) France Aug.2012 43.75457 6.91025 1272 Axel Touchard 3 KU749608 KU749662 KU749761 KU749796

Plateau de Calern 4 Proformica longipilosa sp. nov. Plateau de Calern Cipières (06) France Aug.2012 43.75678 6.90642 1283 Axel Touchard 3 KU749609 KU749663 KU749762 KU749797

Plateau de Calern 6 Proformica longipilosa sp. nov. Plateau de Calern Andon (06) France Aug.2012 43.77595 6.85128 1127 Axel Touchard 3 KU749610 KU749664 KU749763 KU749798

Plateau de Calern 7 Proformica longipilosa sp. nov. Plateau de Calern Caussols (06) France 19.Aug2010 43.7514 6.92349 1264 Christophe Galkowski 2 KU749611, KU749612 KU749665, KU749666 KU749764 KU749799

Plateau de Calern 8 Proformica longipilosa sp. nov. Plateau de Calern Caussols (06) France 19.Aug2010 43.7514 6.92349 1264 Christophe Galkowski KU749667

Plateau de Calern 9 Proformica longipilosa sp. nov. Plateau de Calern Caussols (06) France 19.Aug2010 43.7514 6.92349 1264 Christophe Galkowski KU749668

Plateau de Caussols 1 Proformica longipilosa sp. nov. Plateau de Caussols Gourdon (06) France Jun.2012 43.735046 .946631102 Axel Touchard 3 KU749672

Plateau de Caussols 10 Proformica longipilosa sp. nov. Plateau de Caussols Gourdon (06) France 19Aug.2010 43.7331 6.94244 1115 Christophe Galkowski KU749669

Plateau de Caussols 11 Proformica longipilosa sp. nov. Plateau de Caussols Gourdon (06) France 19Aug.2010 43.7331 6.94244 1115 Christophe Galkowski KU749613 KU749670 KU749765 KU749800

Plateau de Caussols 19 Proformica longipilosa sp. nov. Plateau de Caussols Gourdon (06) France 19Aug.2010 43.7331 6.94244 1115 Christophe Galkowski 3 KU749671

Plateau de Caussols 2 Proformica longipilosa sp. nov. Plateau de Caussols Gourdon (06) France Jun.2012 43.73497 6.94676 1100 Axel Touchard 3 KU749673

Plateau de Caussols 3 Proformica longipilosa sp. nov. Plateau de Caussols Gourdon (06) France Jun.2012 43.73488 6.94681 1100 Axel Touchard 3 KU749674

Plateau de Caussols 4 Proformica longipilosa sp. nov. Plateau de Caussols Gourdon (06) France Jun.2012 43.73493 6.94699 1098 Axel Touchard 2 
Plateau de Caussols 5 Proformica longipilosa sp. nov. Plateau de Caussols Caussols (06) France Aug.2012 43.7219 6.90923 1124 Axel Touchard 3 KU749614 KU749675 KU749766 KU749801

Plateau de Caussols 6 Proformica longipilosa sp. nov. Plateau de Caussols Caussols (06) France Aug.2012 43.72737 6.93098 1139 Axel Touchard 3 KU749615 KU749676 KU749767 KU749802

Plateau de Caussols 7 Proformica longipilosa sp. nov. Plateau de Caussols Gourdon (06) France Aug.2012 43.73065 6.97157 1033 Axel Touchard 3 KU749677

Collias 1 Proformica nasuta Collias Collias (30) France 12Jun.2010 43.947721 4.462309 162 Rumsais Blatrix 5

Plaine de la Crau 1 Proformica nasuta Plaine de la Crau Saint-Martin-de-Crau (13) France Jun.2011 43.583334.83333 19 Claude Lebas 5 KU749616 KU749678 KU749768 KU749803

Plaine de la Crau 2 Proformica nasuta Plaine de la Crau Saint-Martin-de-Crau (13) France Aug.2011 43.58333 4.83333 19 Claude Lebas 5 Plaine de la Crau 3 Proformica nasuta Plaine de la Crau Saint-Martin-de-Crau (13) France Aug.2011 43.58333 4.83333 19 Claude Lebas 5 KU749679

Plaine de la Crau 4 Proformica nasuta Plaine de la Crau Saint-Martin-de-Crau (13) France Aug.2011 43.58333 4.83333 19 Claude Lebas 3 Gréolières 7 Proformica longipilosa sp. nov. Gréolières Gréolières (06) France Aug.2012 43.82862 6.94738 1409 Axel Touchard 3 KU749617 KU749680 KU749769 KU749804

Gréolières 8 Proformica longipilosa sp. nov. Gréolières Gréolières (06) France Aug.2012 43.81688 6.8898 1202 Axel Touchard 3 KU749770 KU749805

Grospierres 1 Proformica nasuta Grospierres Grospierres (07) France 6Jul.2012 44.41163 4.27133 102 Théotime Colin 3 KU749682 Grospierres 10 Proformica nasuta Grospierres Grospierres (07) France 6Jul.2012 44.41163 4.27133102 Théotime Colin 3 KU749681 Grospierres 2 Proformica nasuta Grospierres Grospierres (07) France 6Jul.2012 44.41163 4.27133 102 Théotime Colin 3 KU749618 KU749683 KU749771 KU749806

Grospierres 3 Proformica nasuta Grospierres Grospierres (07) France 6Jul.2012 44.41163 4.27133 102 Théotime Colin 3 KU749684 Grospierres 4 Proformica nasuta Grospierres Grospierres (07) France 6Jul.2012 44.41163 4.27133 102 Théotime Colin 3 KU749619 KU749685 KU749772 KU749807

Grospierres 5 Proformica nasuta Grospierres Grospierres (07) France 6Jul.2012 44.41163 4.27133 102 Théotime Colin 3 KU749686 Grospierres 6 Proformica nasuta Grospierres Grospierres (07) France 6Jul.2012 44.41163 4.27133 102 Théotime Colin 3 KU749687 Grospierres 7 Proformica nasuta Grospierres Grospierres (07) France 6Jul.2012 44.41163 4.27133 102 Théotime Colin 3 KU749688 Grospierres 8 Proformica nasuta Grospierres Grospierres (07) France 6Jul.2012 44.41163 4.27133 102 Théotime Colin 3 KU749689 Grospierres 9 Proformica nasuta Grospierres Grospierres (07) France 6Jul.2012 44.41163 4.27133102 ThÃ@otime Colin 3 KU749690 Jonquières 1 Proformica nasuta Jonquières Jonquières-Saint-Vincent (30) France 11May2011 43.831444.5765321 Rumsais Blatrix 2 KU749620 KU749691, KU749692

Jonquières 2 Proformica nasuta Jonquières Jonquières-Saint-Vincent (30) France 11May2011 43.83144 4.57653 21 Rumsais Blatrix 2 KU749621 KU749693 KU749773 KU749808

Jonquières 3 Proformica nasuta Jonquières Jonquières-Saint-Vincent (30) France 11May2011 43.831444.57653 21 Rumsais Blatrix 3 KU749622 KU749694, KU749695

Jonquières F Proformica nasuta Jonquières Jonquières-Saint-Vincent (30) France 11May2011 43.83144 4.57653 21 Rumsais Blatrix KU749696

Grand Luberon 1 Proformica nasuta Grand Luberon Castellet (84) France 2Jun.2012 43.817135 .47821038 Rumsais Blatrix 3 KU749623 KU749697 KU749774 KU749809

Grand Luberon 2 Proformica nasuta Grand Luberon Castellet (84) France 2Jun.2012 43.81716 5.47816 1038 Rumsais Blatrix 4 KU749698 Grand Luberon 3 Proformica nasuta Grand Luberon Castellet (84) France 2Jun.2012 43.81689 5.47868 1040 Rumsais Blatrix 3 KU749699 Grand Luberon 4 Proformica nasuta Grand Luberon Cabrières-d'Aigues (84) France 2Jun.2012 43.81662 5.478 1050 Rumsais Blatrix 3 KU749700

Grand Luberon 5 Proformica nasuta Grand Luberon Castellet (84) France 2Jun.2012 43.81677 5.47548 1091 Rumsais Blatrix 3 KU749701 Grand Luberon 6 Proformica nasuta Grand Luberon Cabrières-d'Aigues (84) France 2Jun.2012 43.8155 5.47376 1085 Rumsais Blatrix 3 KU749702

Grand Luberon 7 Proformica nasuta Grand Luberon Cabrières-d'Aigues (84) France 2Jun.2012 43.81543 5.47168 1086 Rumsais Blatrix 3 KU749703

Grand Luberon 8 Proformica nasuta Grand Luberon Castellet (84) France 2Jun.2012 43.81574 5.46942 1091 Rumsais Blatrix 3 KU749704 Grand Luberon 9 Proformica nasuta Grand Luberon Castellet (84) France 2Jun.2012 43.81941 5.46737 1047 Rumsais Blatrix 3 KU749624 KU749705 KU749775 KU749810

Montagne de Lure 1 Proformica nasuta Montagne de Lure Châteauneuf-Val-Saint-Donat (04) France 16Jun.2012 44.11319 5.88414 1416 Rumsais Blatrix 3 KU749706 KU749776 KU749811

Montagne de Lure 2 Proformica nasuta Montagne de Lure Châteauneuf-Val-Saint-Donat (04) France 16Jun.2012 44.11317 5.88399 1417 Rumsais Blatrix 3 KU749707

Montagne de Lure 3 Proformica nasuta Montagne de Lure Châteauneuf-Val-Saint-Donat (04) France 16Jun.2012 44.11314 5.88378 1419 Rumsais Blatrix 3 KU749708 
Montagne de Lure 4 Proformica nasuta Montagne de Lure Châteauneuf-Val-Saint-Donat (04) France 16Jun.2012 44.11312 5.8837 1419 Rumsais Blatrix 3 KU749709

Montagne de Lure 5 Proformica nasuta Montagne de Lure Châteauneuf-Val-Saint-Donat (04) France 16Jun.2012 44.1131 5.88352 1419 Rumsais Blatrix 3 KU749710 KU749777 KU749812

Montpellier 1 Proformica nasuta Montpellier Montpellier (34) France 8Mar.2012 43.62914 3.89072 38 Rumsais Blatrix 2 KU749711 Montpellier 2 Proformica nasuta Montpellier Montpellier (34) France 8Mar.2012 43.62925 3.89072 40 Rumsais Blatrix 1 KU749712 Orange 1 Proformica longipilosa sp. nov. Orange Orange (84) France 14Jul.2011 44.13486 4.8081793 Rumsais Blatrix 82 KU749625, KU749626 KU749713 KU749778 KU749813

Orange 2 Proformica longipilosa sp. nov. Orange Orange (84) France 14Jul.2011 44.1345 4.8084 96 Rumsais Blatrix 1

Orange 3 Proformica longipilosa sp. nov. Orange Orange (84) France 14Jul.2011 44.13394 4.80864 99 Rumsais Blatrix 4 KU749627 KU749714 KU749779 KU749814

Sainte-Baume 1 Proformica nasuta Sainte-Baume Riboux (83) France 3Jun.2011 43.32738 5.77002 950 Rumsais Blatrix 3 KU749628, KU749629, KU749630 KU749721, KU749722 KU749780 KU749815

Sainte-Baume 11 Proformica nasuta Sainte-Baume Cuges-les-pins (13) France Jul.2012 43.31528 5.71057 1012 Claude Lebas 41 KU749715

Sainte-Baume 12 Proformica nasuta Sainte-Baume Cuges-les-pins (13) France Jul.2012 43.31495 5.70795 1009 Claude Lebas 4 KU749716 Sainte-Baume 13 Proformica nasuta Sainte-Baume Cuges-les-pins (13) France Jul.2012 43.31528 5.71057 1012 Claude Lebas 3 KU749717 Sainte-Baume 14 Proformica nasuta Sainte-Baume Plan-d'Aups-Sainte-Baume (83) France Jul.2012 43.31582 5.70975 1017 Claude Lebas KU749718

Sainte-Baume 15 Proformica nasuta Sainte-Baume Cuges-les-pins (13) France Jul.2012 43.31468 5.70517 996 Claude Lebas KU749719 Sainte-Baume 16 Proformica nasuta Sainte-Baume Cuges-les-pins (13) France Jul.2012 43.31468 5.70517 996 Claude Lebas KU749720 Sainte-Baume 2 Proformica nasuta Sainte-Baume Riboux (83) France 3Jun.2011 43.32738 5.77002 950 Rumsais Blatrix KU749632, KU749633 KU749725

Sainte-Baume 21 Proformica nasuta Sainte-Baume Plan-d'Aups-Sainte-Baume (83) France Jul.2012 43.31937 5.68035 864 Claude Lebas KU749631 KU749723 KU749781 KU749816

Sainte-Baume 22 Proformica nasuta Sainte-Baume Plan-d'Aups-Sainte-Baume (83) France Jul.2012 43.31937 5.68035 864 Claude Lebas 3 KU749724

Sainte-Baume 3 Proformica nasuta Sainte-Baume Riboux (83) France 3Jun.2011 43.32738 5.77002 950 Christophe Galkowski 4 KU749726 Sainte-Baume 4 Proformica nasuta Sainte-Baume Riboux (83) France 3Jun.2011 43.32738 5.77002 950 Christophe Galkowski 5 KU749727 Sainte-Baume 5 Proformica nasuta Sainte-Baume Riboux (83) France Aug.2011 43.32738 5.77002 950 Claude Lebas 4 KU749728 Sainte-Baume 6 Proformica nasuta Sainte-Baume Riboux (83) France Aug.2011 43.32738 5.77002 950 Claude Lebas 4 KU749729, KU749730

Sainte-Baume 7 Proformica nasuta Sainte-Baume Riboux (83) France 10Sep.2011 43.32738 5.77002 950 Rumsais Blatrix 4 KU749731 Sainte-Baume 8 Proformica nasuta Sainte-Baume Riboux (83) France 10Sep.2011 43.32738 5.77002 950 Rumsais Blatrix 4 KU749732 Sainte-Baume 9 Proformica nasuta Sainte-Baume Riboux (83) France 10Sep.2011 43.32738 5.77002 950 Rumsais Blatrix 4 KU749733 Pompignan 1 Proformica nasuta Pompignan Pompignan (30) France May2010 43.89747 3.82489 199 Rumsais Blatrix 1 KU749636 KU749735 KU749782 KU749817

Pompignan 10 Proformica nasuta Pompignan Pompignan (30) France 10Jul.2011 43.899 3.82611 196 Rumsais Blatrix, Philippe Wegnez 2 KU749634, KU749635 KU749734

Pompignan 2 Proformica nasuta Pompignan Pompignan (30) France May2010 43.89747 3.82489 199 Rumsais Blatrix 1 KU749637 KU749736, KU749737 KU749783 KU749818

Pompignan 3 Proformica nasuta Pompignan Pompignan (30) France May2010 43.89747 3.82489 199 Rumsais Blatrix 1 Sauteyrargues 1 Proformica nasuta Sauteyrargues Sauteyrargues (34) France 28May2011 43.82753 .91917118 Rumsais Blatrix 2 KU749641 KU749739 KU749788 KU749823

Sauteyrargues 2 Proformica nasuta Sauteyrargues Sauteyrargues (34) France 28May2011 43.8275 3.91917 118 Rumsais Blatrix 3 KU749740 Sisteron 1 Proformica longipilosa sp. nov. Sisteron Sisteron (04) France 17Jun.2012 44.19895 5.94151 554 Rumsais Blatrix 3 KU749642 KU749741 KU749789 KU749824

Sisteron 2 Proformica longipilosa sp. nov. Sisteron Sisteron (04) France 17Jun.2012 44.19872 5.94217 558 Rumsais Blatrix 3 KU749742

Sisteron 3 Proformica longipilosa sp. nov. Sisteron Sisteron (04) France 17Jun.2012 44.19898 5.9419 558 Rumsais Blatrix 3 KU749743

Sisteron 4 Proformica longipilosa sp. nov. Sisteron Sisteron (04) France 17Jun.2012 44.19915.94187558 Rumsais Blatrix 3 KU749643 KU749744 KU749790 KU749825

Sumène 1 Proformica nasuta Montagne de la Fage Sumène (30) France 9Apr.2012 43.99044 3.7714 929 Rumsais Blatrix 3 KU749644 KU749745

Sumène 2 Proformica nasuta Montagne de la Fage Sumène (30) France 9Apr.2012 43.99044 3.7714 929 Rumsais Blatrix 3 KU749746 Tarascon 1 Proformica nasuta Tarascon Tarascon (13) France 9Jul.2011 43.84189 4.73778 15 Rumsais Blatrix, Claude Lebas 41 KU749645 KU749747

Tarascon 2 Proformica nasuta Tarascon Tarascon (13) France 9Jul.2011 43.84186 4.73744 16 Rumsais Blatrix, Claude Lebas 4 KU749748 
Tarascon 3 Proformica nasuta Tarascon Tarascon (13) France 9Jul.2011 43.84247 4.7395 16 Rumsais Blatrix, Claude Lebas 4 KU749646 KU749749

Mont Ventoux 1 Proformica longipilosa sp. nov. Mont Ventoux, Chalet Reynard Bedoin (84) France 200944.151585 .323191466 Christophe Galkowski 3 KU749652 KU749756 KU749791 KU749826

Mont Ventoux 10 Proformica longipilosa sp. nov. Mont Ventoux, Chalet Reynard Bedoin (84) France 14Jul.2011 44.152615 .320811442 Rumsais Blatrix 4 KU749647, KU749648 KU749750

Mont Ventoux 11 Proformica longipilosa sp. nov. Mont Ventoux, Chalet Reynard Bedoin (84) France 14Jul.2011 44.151585 .323191466 Rumsais Blatrix 41 KU749649 KU749751

Mont Ventoux 12 Proformica longipilosa sp. nov. Mont Ventoux, Chalet Reynard Bedoin (84) France 14Jul.2011 44.152315 .319391425 Rumsais Blatrix 4 KU749650 KU749752

Mont Ventoux 13 Proformica longipilosa sp. nov. Mont Ventoux, Chalet Reynard Bedoin (84) France 14Jul.2011 44.15183 5.32328 1466 Rumsais Blatrix 4 KU749651 KU749753

Mont Ventoux 14 Proformica longipilosa sp. nov. Mont Ventoux, Chalet Reynard Bedoin (84) France 14Jul.2011 44.15215 .32321473 Philippe Wegnez KU749754

Mont Ventoux 15 Proformica longipilosa sp. nov. Mont Ventoux, Chalet Reynard Bedoin (84) France Aug.2011 44.1521 5.3232 1473 Claude Lebas 4 KU749755

Mont Ventoux 16 Proformica longipilosa sp. nov. Mont Ventoux, Chalet Reynard Bedoin (84) France Aug.2011 44.1521 5.3232 1473 Claude Lebas 4

Mont Ventoux 2 Proformica longipilosa sp. nov. Mont Ventoux, Chalet Reynard Bedoin (84) France 200944.151585 .323191466 Christophe Galkowski 81 KU749653 KU749757 KU749792 KU749827

Mont Ventoux 3 Proformica longipilosa sp. nov. Mont Ventoux, Chalet Reynard Bedoin (84) France 200944.151585 .323191466 Christophe Galkowski 3

Mont Ventoux 4 Proformica longipilosa sp. nov. Mont Ventoux, Chalet Reynard Bedoin (84) France 200944.151585 .323191466 Christophe Galkowski 3

Vinsobre 1 Proformica longipilosa sp. nov. Vinsobre Vinsobre (84) France Aug.2012 44.333335 .05972297 Philippe Wegnez KU749654 KU749758 KU749793 KU749828

Appendix 2. Measurements of morphological characters for 321 workers of Proformica from southern France.

colony CW nCH nCU nTx nSe nG PDG GHL

Aurons 11190122251770

Aurons 1850021051850

Aurons 1545011111135

Aurons 158000000140

Beaucaire 11240010021442

Beaucaire 11150020011460

Beaucaire 1990010021450

Beaucaire 1715000021550

Beaucaire 2815000011760

Beaucaire 260000000200

Beaucaire 2650000021550

Beaucaire 3885000021735

Beaucaire 359500000110

Beaucaire 3615001021550

Beaucaire 4935010031450

Beaucaire 4920000021350

Beaucaire 468000000170

Beaucaire 4615000111550

Bonnieux 160000000170

Bonnieux 1680000021835

Bonnieux 170000100210

Bonnieux 1680000021735

Bonnieux 273000200240

Bonnieux 2615000022842

Bonnieux 261500000170
Bonnieux 2715000022142

Plateau de Calern 101020782031842155

Plateau de Calern 10900562341042136

Plateau de Calern 1073172103542102

Plateau de Calern 106635364742145

Plateau de Calern 181530101375223856221

Plateau de Calern 1812758837112856187

Plateau de Calern 181225653372268204

Plateau de Calern 18612127494285

Plateau de Calern 71070682742856170

Plateau de Calern 7663651321042155

Plateau de Calern 211007153482042200

Plateau de Calern 2715451121538100

Plateau de Calern 2680241131038100

Plateau de Calern 3120011102783938220

Plateau de Calern 3835972152742170

Plateau de Calern 3715281261642170

Plateau de Calern 412251054874338200

Plateau de Calern 4765941851742170

Plateau de Calern 476587931338100

Plateau de Calern 6139513176583642200

Plateau de Calern 6700852141538100

Plateau de Calern 6735451851142170

Plateau de Caussols 11350864592656190

Plateau de Caussols 11170984052248170 
Plateau de Caussols 1715641821342102

Plateau de Caussols 191275463693256221

Plateau de Caussols 19918382462568155

Plateau de Caussols 1971414165745130

Plateau de Caussols 2132512957103848170

Plateau de Caussols 21445864253748200

Plateau de Caussols 21120693052948170

Plateau de Caussols 31170343063256155

Plateau de Caussols 3830642152242120

Plateau de Caussols 35453211264268

Plateau de Caussols 41260674473256190

Plateau de Caussols 4730451441242102

Plateau de Caussols 5146091754143756220

Plateau de Caussols 59501063182642155

Plateau de Caussols 565033421142100

Plateau de Caussols 61325151360123556190

Plateau de Caussols 610201272641538140

Plateau de Caussols 6615231021038120

Plateau de Caussols 7136010114673148170

Plateau de Caussols 7780531241842100

Plateau de Caussols 76803393842100

Collias 11160022071476

Collias 1580001021250

Collias 1660000011268

Collias 1731000011175

Collias 165000000110

Plaine de la Crau 11000027021850

Plaine de la Crau 1870000021435

Plaine de la Crau 181500200140

Plaine de la Crau 166500000140

Plaine de la Crau 1615000021245

Plaine de la Crau 2885033011560

Plaine de la Crau 285002520170

Plaine de la Crau 260000100140

Plaine de la Crau 257500000140

Plaine de la Crau 2650000011450

Plaine de la Crau 3900033331750

Plaine de la Crau 357500011935

Plaine de la Crau 361500000110

Plaine de la Crau 3715010011135

Plaine de la Crau 3600010121250

Plaine de la Crau 41090004231760

Plaine de la Crau 4800000011435

Plaine de la Crau 4850001031460

Gréolières 712401373392348170

Gréolières 7850841151542155

Gréolières 7665231031042100

Gréolières 81325895983548240

Gréolières 881567175942155

Gréolières 864534123738140

Grospierres 1850023211050

Grospierres 1715010011035

Grospierres 156000000100
Grospierres 10815213141050

Grospierres 1071500000120

Grospierres 10600000011435

Grospierres 2870001021035

Grospierres 261500100120

Grospierres 26150000090

Grospierres 385000002935

Grospierres 3680010111235

Grospierres 354500000120

Grospierres 4920015131460

Grospierres 471500000120

Grospierres 4650000011035

Grospierres 5730004031050

Grospierres 5650000011235

Grospierres 558000101935

Grospierres 6920105041050

Grospierres 66500000090

Grospierres 6615000011235

Grospierres 7935106431035

Grospierres 775000302935

Grospierres 7665001011235

Grospierres 8850106031250

Grospierres 881000010120

Grospierres 8715002021235

Grospierres 9870204141250

Grospierres 957500000100

Grospierres 955000000100

Jonquières 1112000000120

Jonquières 16630000011268

Jonquières 21050000021450

Jonquières 2714000011268

Jonquières 3952001011460

Jonquières 31020000031450

Jonquières 3663001011250

Grand Luberon 1139565283101485

Grand Luberon 110702216482168

Grand Luberon 1750228461468

Grand Luberon 210004514581468

Grand Luberon 29704616162168

Grand Luberon 2665418132150

Grand Luberon 2580205022450

Grand Luberon 312907421271785

Grand Luberon 38003410373468

Grand Luberon 3680434313435

Grand Luberon 410203413231468

Grand Luberon 4665413452485

Grand Luberon 4630425353460

Grand Luberon 5120086164141468

Grand Luberon 5935403173468

Grand Luberon 5760436273460

Grand Luberon 612606319561768

Grand Luberon 610202312591768

Grand Luberon 6665327131450 
Grand Luberon 711907518291985

Grand Luberon 78657314351950

Grand Luberon 770020000340

Grand Luberon 811905518391475

Grand Luberon 88504415372193

Grand Luberon 8650406042850

Grand Luberon 911206628681768

Grand Luberon 9830229341368

Grand Luberon 9580108142168

Montagne de Lure1 122564127101468

Montagne de Lure 1765219481450

Montagne de Lure 1700015071442

Montagne de Lure 29703313451476

Montagne de Lure 2815117291450

Montagne de Lure 2700127351450

Montagne de Lure 313252419571460

Montagne de Lure 38152311161450

Montagne de Lure 3670214261435

Montagne de Lure 413253523161450

Montagne de Lure 48505592121465

Montagne de Lure 4700235261442

Montagne de Lure 512609625671485

Montagne de Lure 510203215391250

Montagne de Lure 5700217241542

Montpellier 1715000011435

Montpellier 161500000120

Montpellier 2630000011735

Orange 171500112748120

Orange 18841051842140

Orange 168012100442120

Orange 17152191542135

Orange 11350012821637120

Orange 11140022441942120

Orange 186501123856135

Orange 190012133742120

Orange 2580003114285

Orange 393522152942130

Orange 38151042442110

Orange 37001210163795

Orange 37152252542110

Saint-Baume 111406621471560

Saint-Baume 111052512451850

Saint-Baume 1815265321375

Saint-Baume 11120014234123470

Saint-Baume 1111003120152150

Saint-Baume 11630136153450

Saint-Baume 11650113141750

Saint-Baume 12780235063768

Saint-Baume 12680218241742

Saint-Baume 12730132111435

Saint-Baume 12650207321750

Saint-Baume 13985427271435

Saint-Baume 13730032141725
Saint-Baume 13680024142135

Saint-Baume 2210802416581560

Saint-Baume 228651311171550

Saint-Baume 22630005131735

Saint-Baume 311902319332050

Saint-Baume 3833058321750

Saint-Baume 3850048321850

Saint-Baume 3600006112435

Saint-Baume 411406512361570

Saint-Baume 411201513142068

Saint-Baume 411600511371550

Saint-Baume 4645002121250

Saint-Baume 461200410120

Saint-Baume 512752419271460

Saint-Baume 511901115561750

Saint-Baume 5884135411135

Saint-Baume 5665035021450

Saint-Baume 6985158491760

Saint-Baume 6900239451850

Saint-Baume 6630226251450

Saint-Baume 6650006141742

Saint-Baume 710503394101350

Saint-Baume 7870227361750

Saint-Baume 7680016231135

Saint-Baume 7630014221742

Saint-Baume 8115544174101450

Saint-Baume 8935247261542

Saint-Baume 8800335251768

Saint-Baume 8665015331435

Saint-Baume 9730249271750

Saint-Baume 9815148381460

Saint-Baume 9730036351776

Saint-Baume 9650036351450

Pompignan 11200000011276

Pompignan 21170022031168

Pompignan 310900020111.760

Sauteyrargues 175000000120

Sauteyrargues 173000000120

Sauteyrargues 2600000011335

Sauteyrargues 256000000110

Sauteyrargues 2730000021250

Sisteron 18001051831134130

Sisteron 1645831341034120

Sisteron 17001051541134102

Sisteron 212401084152438155

Sisteron 2950662161734145

Sisteron 27508511263468

Sisteron 310351093561834160

Sisteron 38001031341042102

Sisteron 3680621241634110

Sisteron 48151072041634155

Sisteron 47506411283495

Sisteron 46658314194285 
Sumène 163000000110

Sumène 166500000110

Sumène 156000000110

Sumène 2110002000120

Sumène 261501000110

Sumène 261500000140

Tarascon 11120143051760

Tarascon 1920021021750

Tarascon 1920021021445

Tarascon 1715002021250

Tarascon 2990000031490

Tarascon 2870000021550

Tarascon 265000000120

Tarascon 2730000011450

Tarascon 3107000200150

Tarascon 3715000011450

Tarascon 361500000120

Tarascon 3615000021350

Mont Ventoux 11156543161842187

Mont Ventoux 1646321171342170

Mont Ventoux 164642133103785

Mont Ventoux 1013951023482437170

Mont Ventoux 10950472081742190

Mont Ventoux 1081551421148120

Mont Ventoux 10665449173785

Mont Ventoux 111310964782642170

Mont Ventoux 11850651851148170

Mont Ventoux 11700641341037135

Mont Ventoux 1166532135737170

Mont Ventoux 1214451295582742170
Mont Ventoux 121100853451942170

Mont Ventoux 12750651641334140

Mont Ventoux 1260054113734150

Mont Ventoux 1312401344172434190

Mont Ventoux 1311901463351237170

Mont Ventoux 1373054165742140

Mont Ventoux 1366553144742140

Mont Ventoux 1513001353892228205

Mont Ventoux 15115010237101634190

Mont Ventoux 1565042921042105

Mont Ventoux 156801011393785

Mont Ventoux 161020843272542190

Mont Ventoux 16850851561148170

Mont Ventoux 1664083113948155

Mont Ventoux 1665062124948170

Mont Ventoux 2750241641042153

Mont Ventoux 2697231151042153

Mont Ventoux 25861314573485

Mont Ventoux 21240684391742170

Mont Ventoux 213269646121742195

Mont Ventoux 21088753981942170

Mont Ventoux 269724173103493

Mont Ventoux 2730341941242136

Mont Ventoux 31411454172348204

Mont Ventoux 31122703071648187

Mont Ventoux 385042176842102

Mont Ventoux 41326894492156187

Mont Ventoux 41258873482824187

Mont Ventoux 4833431641142170

Appendix 3. Measurements of morphological characters for 10 queens of Proformica from southern France.

colony CW SL nCH nCU nPn nMes nPP nSc nG PDG GHL MW ML ScW

Sainte-Baume 14101130021414851088510702000660

Tarascon 1150012600665821148510902175620

Beaucaire 11530124002112009010202040620

Beaucaire 1163012750400202117011902245665

Pompignan 101665123512110623117011902245800

Pompignan 101690124002111522118512402310865

Orange 117001275321126102251524012752340765

Orange 11530122513153063241721011902245700

Mont Ventoux 1117701395451338168261222014102510815

Mont Ventoux 21750132513720531513361424013202450850 


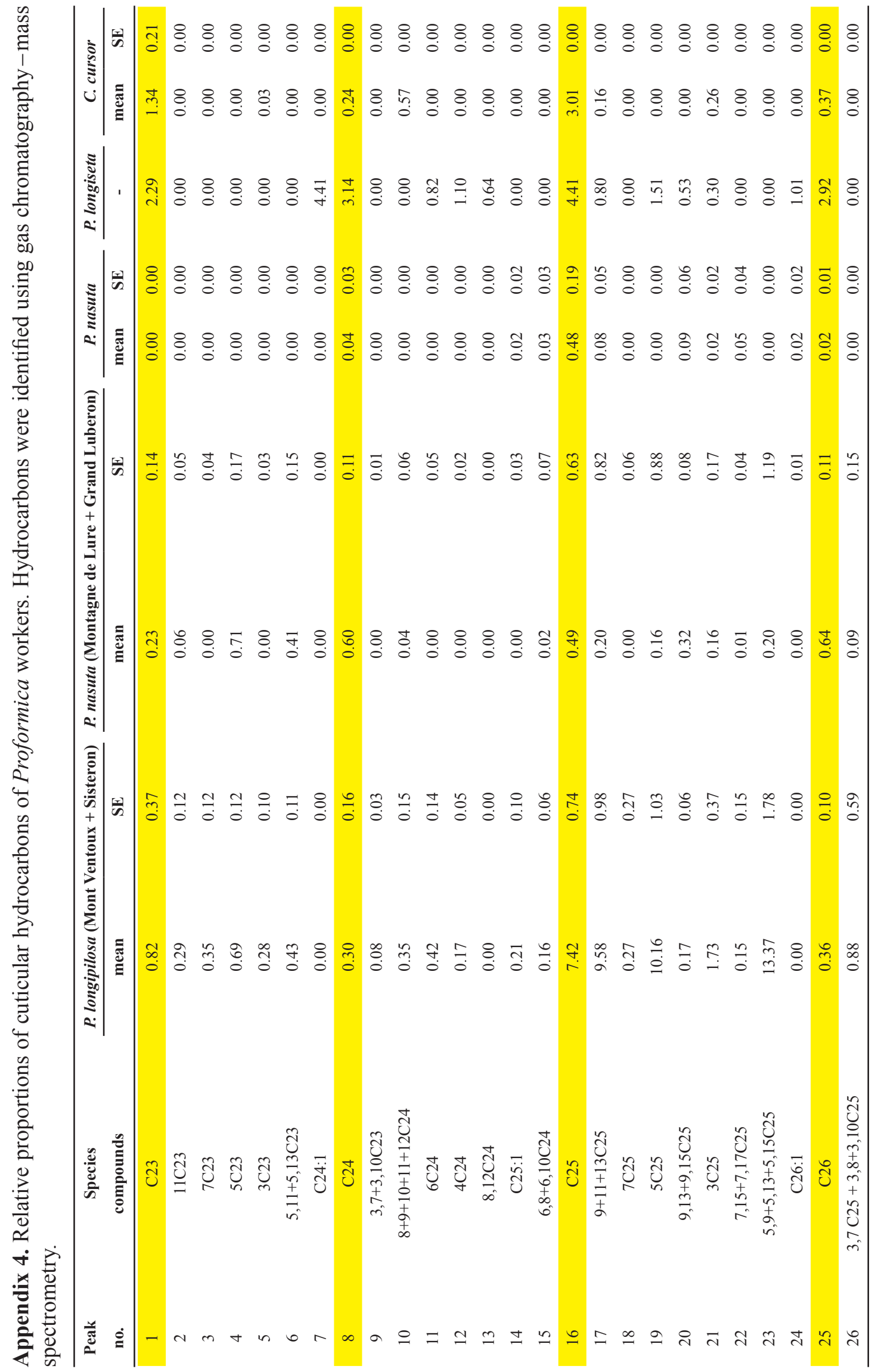




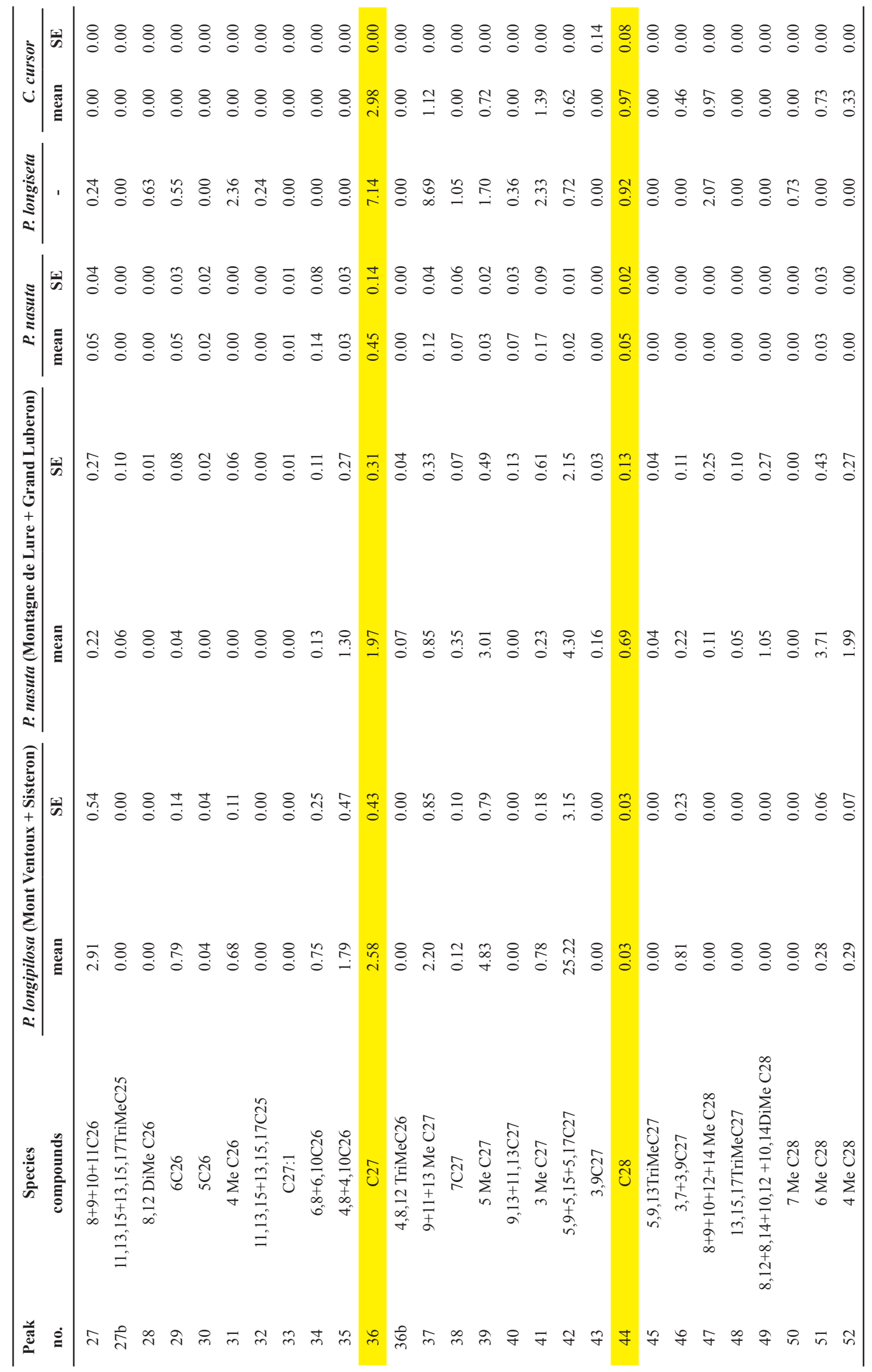




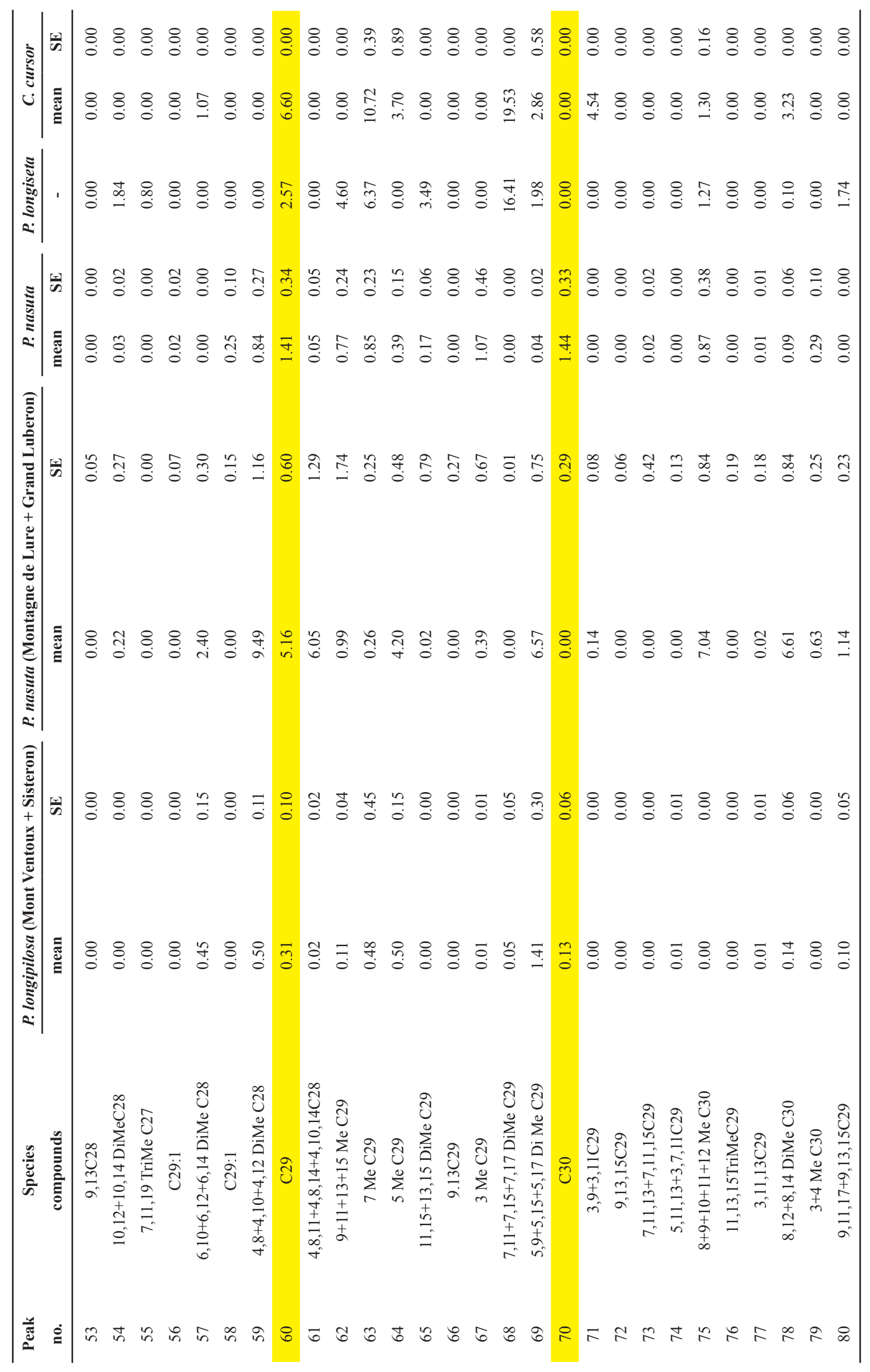




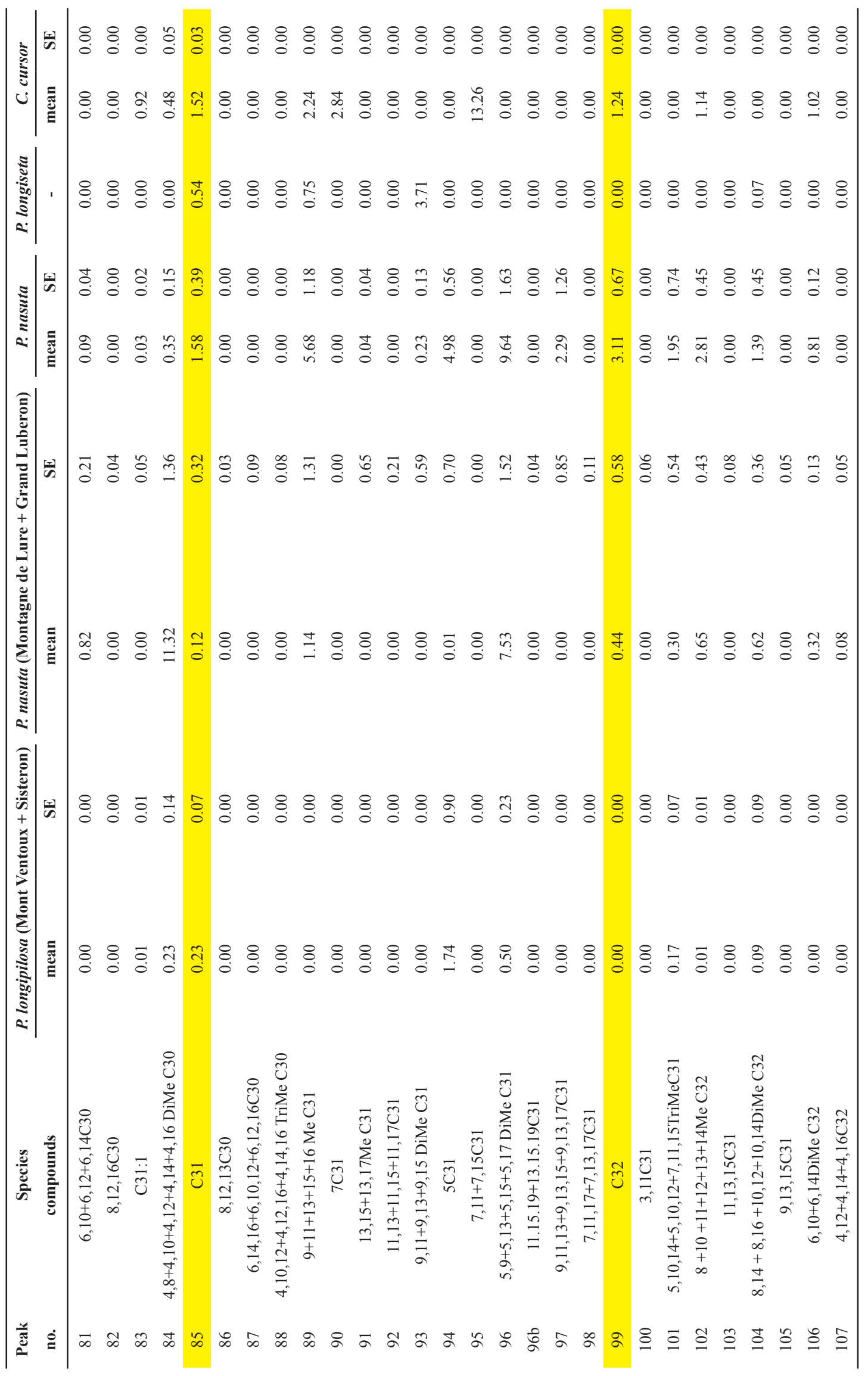




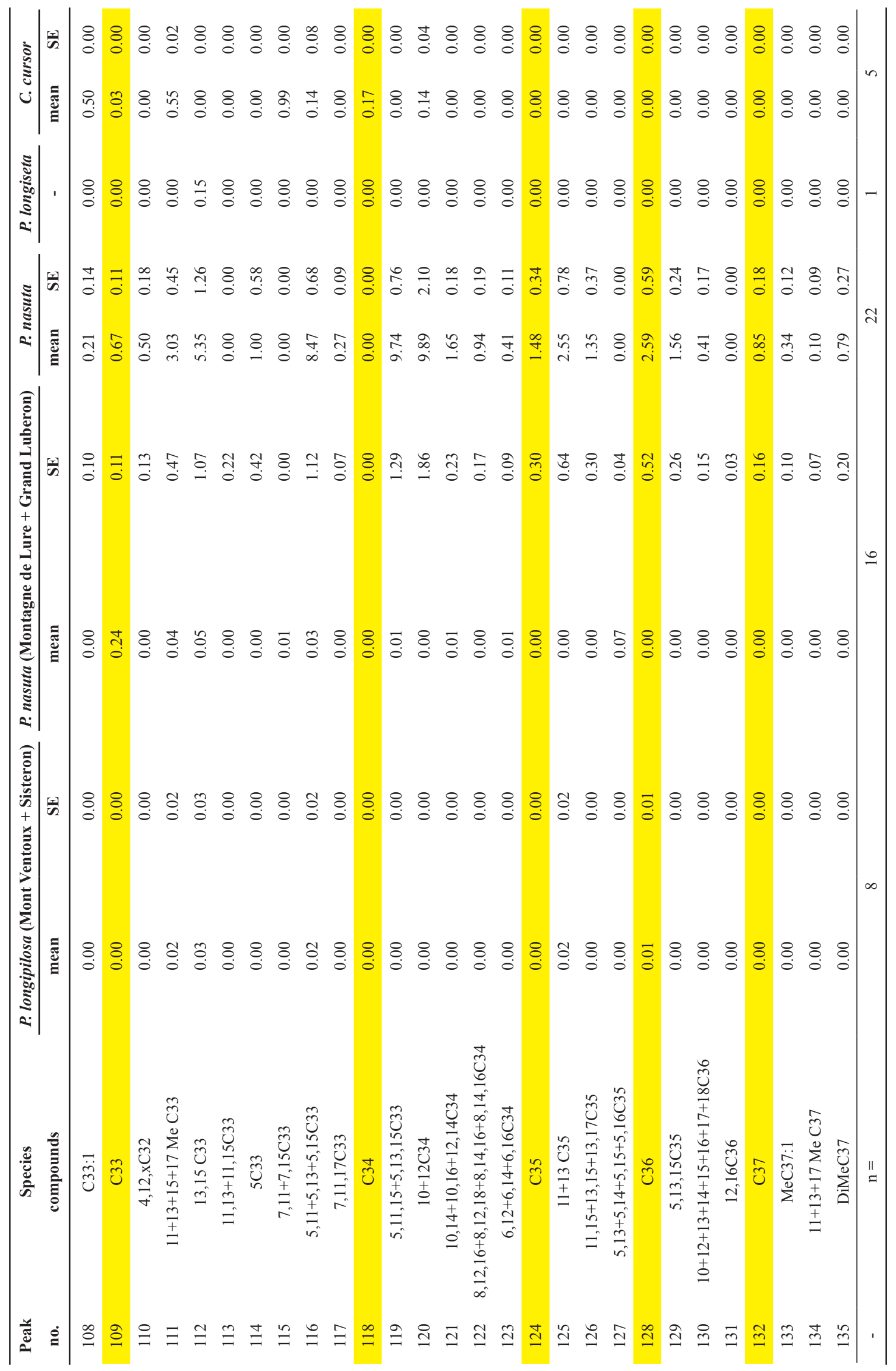




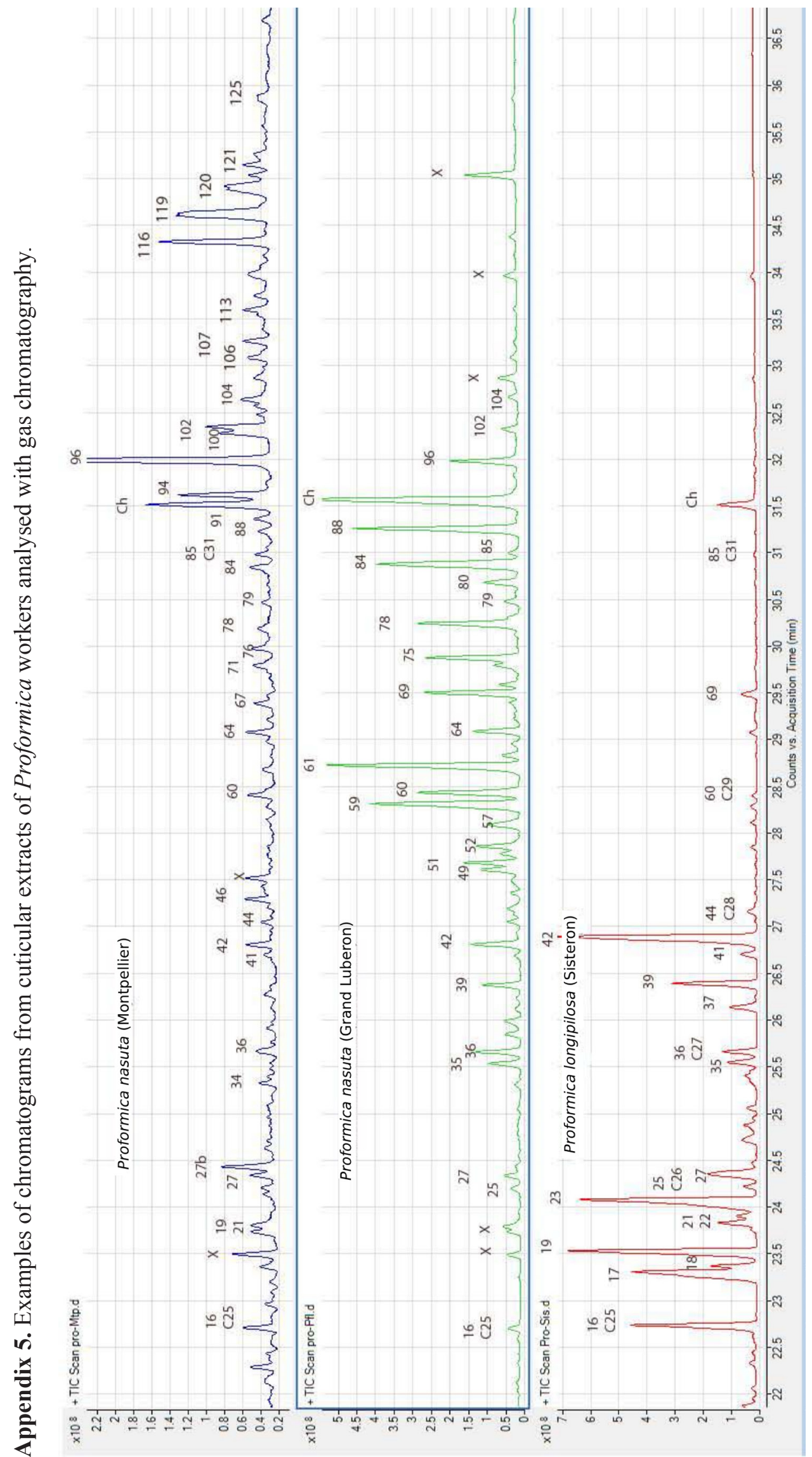

